Prepared in cooperation with the U.S. Army Corps of Engineers

Effects of Hydrologic Modifications on Salinity and Formation of Hypoxia in the Mississippi River-Gulf Outlet and Adjacent Waterways, Southeastern Louisiana, 2008 to 2012

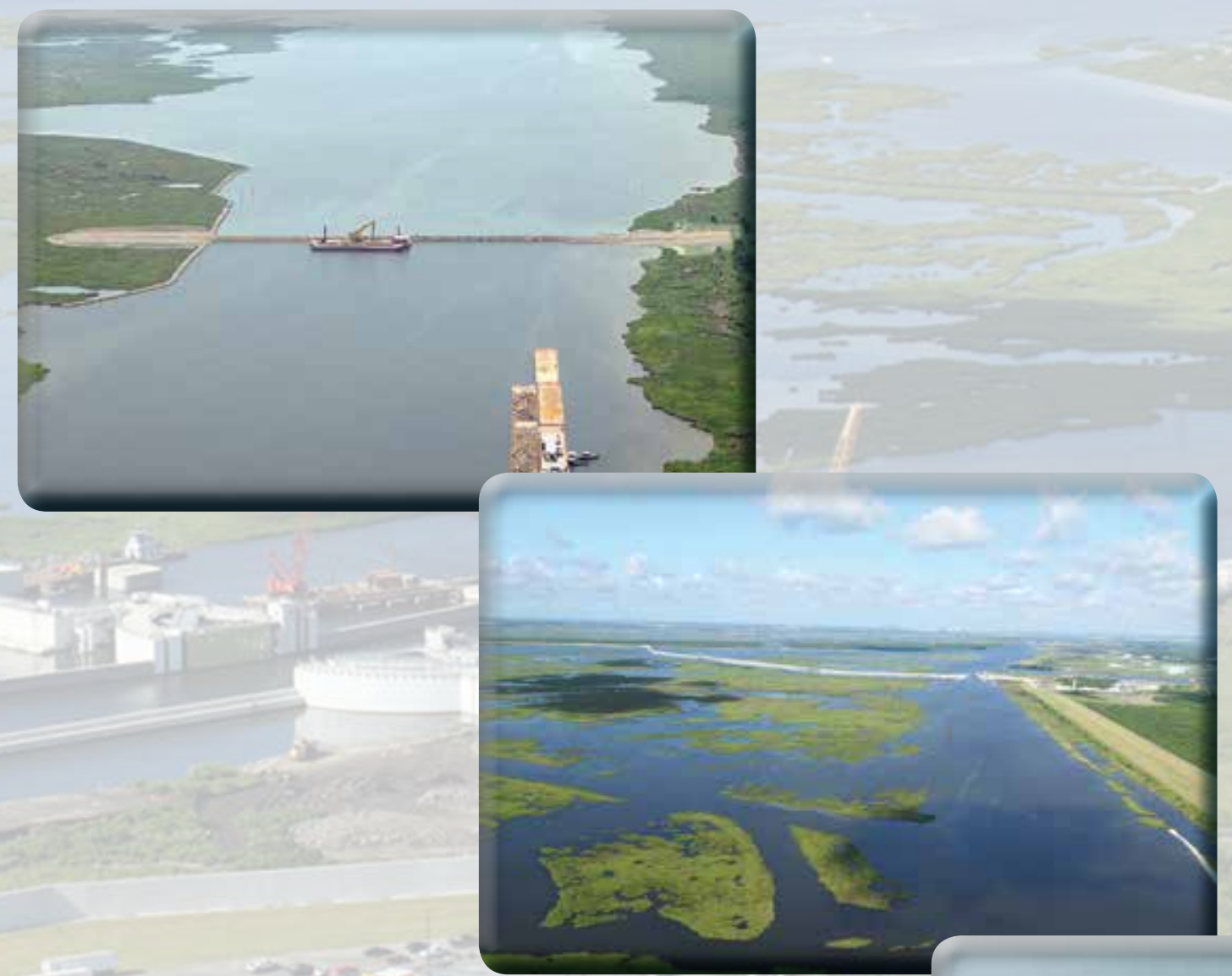

Scientific Investigations Report 2014-5077

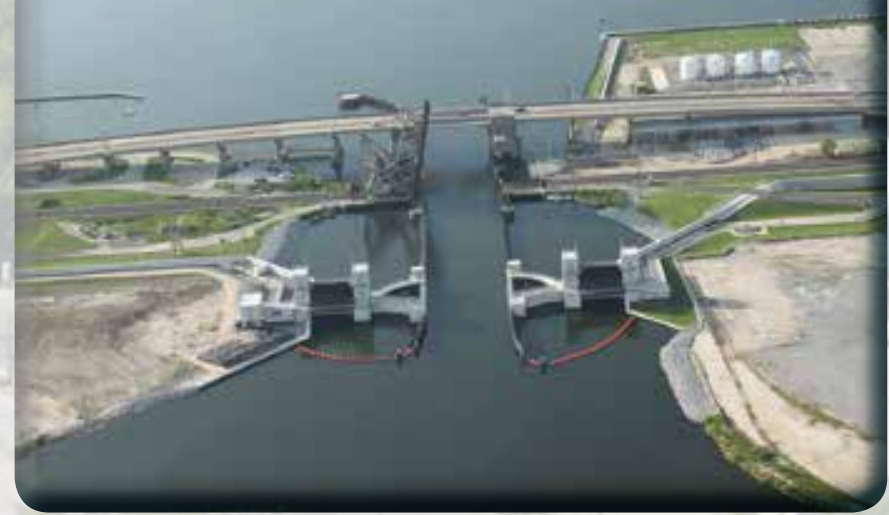




\section{Front cover:}

Top, Looking southward along the Mississippi River-Gulf Outlet at the rock barrier.

Middle, Looking westward along the Gulf Intracoastal Waterway towards the Inner Harbor Navigation Canal-Lake Borgne Surge Barrier.

Bottom, Looking southward from Lake Pontchartrain to the Seabrook floodgate complex and Inner Harbor Navigation (Industrial) Canal.

All photographs courtesy of the U.S. Army Corps of Engineers. 


\section{Effects of Hydrologic Modifications on Salinity and Formation of Hypoxia in the Mississippi River-Gulf Outlet and Adjacent Waterways, Southeastern Louisiana, 2008 to 2012}

By Christopher M. Swarzenski and Scott V. Mize

Prepared in cooperation with the U.S. Army Corps of Engineers

Scientific Investigations Report 2014-5077 


\section{U.S. Department of the Interior \\ SALLY JEWELL, Secretary}

\section{U.S. Geological Survey \\ Suzette M. Kimball, Acting Director}

\section{U.S. Geological Survey, Reston, Virginia: 2014}

For more information on the USGS — the Federal source for science about the Earth, its natural and living resources, natural hazards, and the environment, visit http://www.usgs.gov or call 1-888-ASK-USGS.

For an overview of USGS information products, including maps, imagery, and publications, visit http://www.usgs.gov/pubprod

To order this and other USGS information products, visit http://store.usgs.gov

Any use of trade, firm, or product names is for descriptive purposes only and does not imply endorsement by the U.S. Government.

Although this information product, for the most part, is in the public domain, it also may contain copyrighted materials as noted in the text. Permission to reproduce copyrighted items must be secured from the copyright owner.

Suggested citation:

Swarzenski, C.M., and Mize, S.V., 2014, Effects of hydrologic modifications on salinity and formation of hypoxia in the Mississippi River-Gulf Outlet and adjacent waterways, southeastern Louisiana, 2008 to 2012: U.S. Geological Survey Scientific Investigations Report 2014-5077, 21 p., http://dx.doi.org/10.3133/sir20145077.

ISSN 2328-031X (print)

ISSN 2328-0328 (online)

ISBN 978-1-4113-3803-6 


\section{Acknowledgements}

The authors thank Laura Lee Wilkinson and Barbara Kleiss of the U.S. Army Corps of Engineers for their assistance with the execution of the project. 



\section{Contents}

Acknowledgements .....................................................................................................................ii

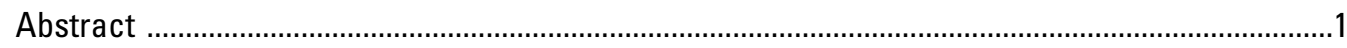

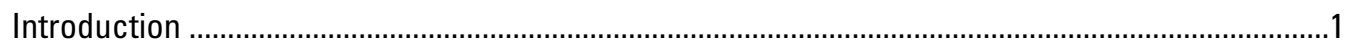

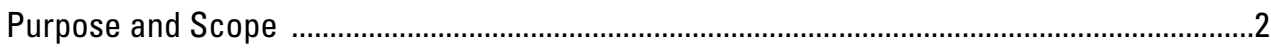

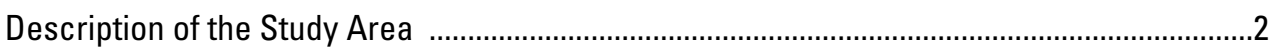

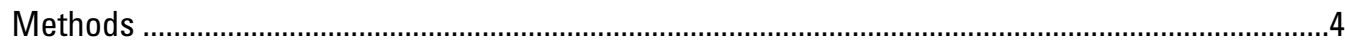

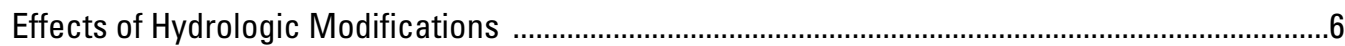

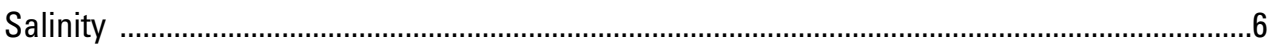

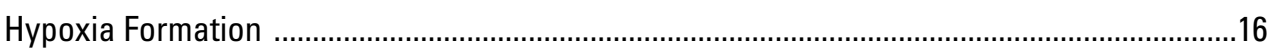

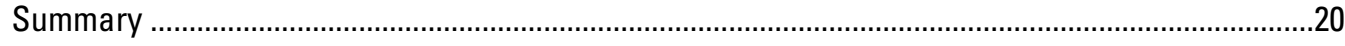

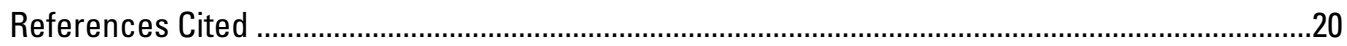

\section{Figures}

1. Map showing location of data-collection sites in the Mississippi River-Gulf Outlet and adjacent waterways, southeastern Louisiana

2. Graph showing continuous salinity in the Inner Harbor Navigation (Industrial) Canal (IHNC), the Mississippi River-Gulf Outlet (MRGO), Lake Pontchartrain, and Lake Borgne in southeastern Louisiana, 2009-12

3. Salinity contours, in parts per thousand, between miles 30 and 59 in the Mississippi River-Gulf Outlet in southeastern Louisiana for August 15, 2008, July 30, 2009, and August 19, 2010

4. Salinity contours, in parts per thousand, between miles 30 and 59 in the Mississippi River-Gulf Outlet in southeastern Louisiana for July 08, 2011, and July 10, 2012

5. Extent of hypoxic layer, between miles 20 and 59 in the Mississippi River-Gulf Outlet in southeastern Louisiana on October 8, 2009; hypoxia occurs when dissolved oxygen concentrations are less than 2 milligrams per liter

6. Vertical profiles of salinity and dissolved oxygen at transects in the Mississippi River-Gulf Outlet (MRGO) and the Gulf Intracoastal Waterway (GIWW) in southeastern Louisiana, June to October 2010

7. Vertical profiles of salinity and dissolved oxygen at transects in the Mississippi River-Gulf Outlet (MRGO) and the Gulf Intracoastal Waterway (GIWW) in southeastern Louisiana, May to October 2011

8. Vertical profiles of salinity and dissolved oxygen at transects in the Mississippi River-Gulf Outlet (MRGO) and the Gulf Intracoastal Waterway (GIWW) in southeastern Louisiana, May to October 2012 


\section{Tables}

1. Data-collection sites in the Mississippi River-Gulf Outlet (MRGO) and adjacent waterways, and in Lake Borgne and Lake Pontchartrain in southeastern Louisiana

2. Water depth below which dissolved oxygen concentrations are less than 2 milligrams per liter, indicating hypoxic conditions, in the Mississippi River-Gulf Outlet (MRGO) and adjacent surface waters in southeastern Louisiana, August 2008 to October 2012

\section{Conversion Factors}

Inch/Pound to SI

\begin{tabular}{lcl}
\hline \multicolumn{1}{c}{ Multiply } & By & \multicolumn{1}{c}{ To obtain } \\
\hline inch (in.) & Length & \\
inch (in.) & 25.4 & millimeters $(\mathrm{mm})$ \\
foot (ft) & 2.54 & centimeter $(\mathrm{cm})$ \\
& 0.3048 & meter $(\mathrm{m})$ \\
\hline square foot $\left(\mathrm{ft}^{2}\right)$ & Area & \\
\hline & 0.09290 & square meter $\left(\mathrm{m}^{2}\right)$ \\
\hline cubic foot $\left(\mathrm{ft}^{3}\right)$ & Volume & cubic meter $\left(\mathrm{m}^{3}\right)$ \\
\hline & 0.02832 & \\
\hline foot per second $(\mathrm{ft} / \mathrm{s})$ & Flow rate & meter per second $(\mathrm{m} / \mathrm{s})$ \\
cubic foot per second $\left(\mathrm{ft}^{3} / \mathrm{s}\right)$ & 0.3048 & cubic meter $\mathrm{per} \mathrm{second}\left(\mathrm{m}^{3} / \mathrm{s}\right)$ \\
\hline
\end{tabular}

Temperature in degrees Celsius $\left({ }^{\circ} \mathrm{C}\right)$ may be converted to degrees Fahrenheit $\left({ }^{\circ} \mathrm{F}\right)$ as follows:

${ }^{\circ} \mathrm{F}=\left(1.8 \mathrm{x}^{\circ} \mathrm{C}\right)+32$

Horizontal coordinate information is referenced to the North American Datum of 1927 (NAD 27).

Specific conductance is given in microsiemens per centimeter at 25 degrees Celsius $(\mu \mathrm{S} / \mathrm{cm}$ at $\left.25^{\circ} \mathrm{C}\right)$.

Concentrations of chemical constituents in water are given either in milligrams per liter ( $\mathrm{mg} / \mathrm{L}$ ) or micrograms per liter $(\mu \mathrm{g} / \mathrm{L})$. 


\title{
Effects of Hydrologic Modifications on Salinity and Formation of Hypoxia in the Mississippi River-Gulf Outlet and Adjacent Waterways, Southeastern Louisiana, 2008 to 2012
}

\author{
By Christopher M. Swarzenski and Scott V. Mize
}

\section{Abstract}

The Mississippi River-Gulf Outlet (MRGO) was constructed between 1958 and 1968 to provide a safer and shorter route between the Gulf of Mexico and the Port of New Orleans for ocean-going vessels. In 2006, the U.S. Congress directed the U.S. Army Corps of Engineers (USACE) to develop and implement a plan to deauthorize a portion of the MRGO ship channel from its confluence with the Gulf Intracoastal Waterway to the Gulf of Mexico. In 2009, in accordance with plans submitted to Congress, the USACE built a rock barrier across the MRGO near Hopedale, Louisiana. Following Hurricane Katrina, Congress also authorized the USACE to implement the Hurricane Storm Damage Risk Reduction System (HSDRRS) by building structures in the MRGO and adjacent surface waters, to reduce vulnerability of this area to storm surge. The HSDRRS includes the Gulf Intracoastal Waterway-Lake Borgne Surge Barrier and Gate Complex near mile 58 of the deauthorized portion of the MRGO and the Seabrook Gate Complex on the Inner Harbor Navigation (Industrial) Canal (IHNC). By blocking or limiting tidal exchange in the MRGO, these barriers could affect water quality in the MRGO and nearby waters including Lake Pontchartrain, the IHNC, and Lake Borgne. In 2008, the U.S. Geological Survey, in cooperation with the USACE, began a study to document the effects of the construction activities on salinity and dissolved oxygen in these surface waters. Data were collected from August 2008 through October 2012.

Completion of the rock barrier in the vicinity of mile 35 in July 2009 reduced hydrologic circulation and separated the MRGO into two distinct salinity regimes, with substantially fresher conditions prevailing upstream from the rock barrier. The rock barrier also contributed to a zone of hypoxia (dissolved oxygen less than 2 milligrams per liter) that formed along the channel bottom during the warmer summer months in each year of this monitoring; the zone was much more developed downstream from the rock barrier. The most extensive hypoxic zone was measured in October 2009 when it extended at least 34 miles in the MRGO, from mile 20 to mile 54. Construction of the surge barrier and floodgates did not affect salinity or dissolved oxygen in any comparable manner.

The factors that contributed the most to hypoxia in the MRGO were the reductions in tidal water movement there after completion of the rock barrier combined with the channel depth in the MRGO, in places 10 to 30 feet deeper than surrounding surface water bodies. These factors helped to stratify salinity by reducing vertical mixing in the water column.

\section{Introduction}

The Mississippi River-Gulf Outlet (MRGO) was authorized by a March 29, 1956, Act of the U.S. Congress (Public Law 84-455) to provide an emergency outlet from the Mississippi River in the interest of National defense and general commerce and as a safer and shorter route between the Port of New Orleans and the Gulf of Mexico (U.S. Army Corps of Engineers, 2010). Construction of the MRGO began in 1958, and the channel was completed in 1968.

In 2006, the U.S. Congress directed the Secretary of the Army, acting through the Chief of Engineers, to plan for deauthorization of the MRGO from the Gulf Intracoastal Waterway (GIWW) to the Gulf of Mexico. The USACE began a study to develop a comprehensive plan to deauthorize deep-draft navigation, evaluate any navigation functions that should be maintained, and to be consistent with Louisiana's Comprehensive Master Plan for a Sustainable Coast (Coastal Protection and Restoration Authority of Louisiana, 2007). The final Deep-Draft Deauthorization Report was sent to Congress on June 5, 2008, officially deauthorizing the channel from the GIWW to the Gulf of Mexico and authorizing the construction of a rock closure structure (barrier) across the channel near Hopedale, Louisiana (U.S. Army Corp of Engineers, 2010). 
Following Hurricane Katrina, Congress also authorized the USACE to implement the Hurricane Storm Damage Risk Reduction System (HSDRRS) by building structures in the MRGO and adjacent surface waters to reduce vulnerability of this area to storm surge. The HSDRRS included the Lake Borgne Surge Barrier and Gate Complex, hereafter referred to as the "surge barrier," and included a 2-mile long surge barrier crossing the marshland just east of the Inner Harbor Navigation (Industrial) Canal (IHNC), a navigable sector gate along the GIWW, an adjacent bypass barge gate, and a navigable lift gate at Bayou Bienvenue (U.S. Army Corps of Engineers, 2013a). This combination of surge barrier and navigable gates serves to reduce risk from hurricane and tropical event storm surge entering the area from Lake Borgne and the Gulf of Mexico. The Seabrook Gate Complex, hereafter referred to as the "Seabrook floodgates," is located just south of where the IHNC enters Lake Pontchartrain. The Seabrook floodgates include a navigable sector gate and two nonnavigable lift gates. In coordination with the surge barrier and gates, they reduce the risk of hurricane and tropical event storm surge entering the area from Lake Pontchartrain. By blocking or limiting tidal exchange in the MRGO, these barriers could affect water quality in the MRGO and nearby surrounding waters such as Lake Pontchartrain, the IHNC, and Lake Borgne.

In 2008, in cooperation with the Louisiana Coastal Area Science and Technology Program (a collaboration between the USACE and the Coastal Protection and Restoration Authority of Louisiana), the U.S. Geological Survey (USGS) began a study to document the impacts of the rock barrier before, during, and after its construction. Water-quality, bedsediment, and discharge data collected during 2008-9 were published in Swarzenski and others (2012). In 2010, the study was continued solely in cooperation with the USACE. The focus of the data collection shifted to the waters north of the rock barrier more directly affected by the surge barrier and the Seabrook floodgates. Only water-quality information was collected. Additional sampling stations were added in the vicinity of the surge barrier and near construction activities (fig. 1). Sampling stations downstream from the rock barrier were discontinued.

\section{Purpose and Scope}

This report presents salinity and dissolved oxygen data collected in the MRGO and adjacent waterways and discusses effects of hydrologic barriers on patterns of hypoxia that occurred in these waterways from August 2008 to October 2012. Hypoxia refers to conditions when dissolved oxygen concentrations in the water column drop below 2 milligrams per liter $(\mathrm{mg} / \mathrm{L})$ (Committee on Environment and Natural Resources, 2003). The data represent conditions in the MRGO before, during, and after construction of the rock barrier across the MRGO near Hopedale. The data also represent conditions before, during, and after construction of the surge barrier and the Seabrook floodgates. Discrete measurements of dissolved oxygen and salinity and continuous salinity data collected in the MRGO upstream, in between, and downstream from the two barriers, as well as in Lake Borgne, Violet Canal, and the IHNC, are presented in tables and figures. Additionally, starting in 2010, 5 sites in smaller waterways that had historically been sampled by the Louisiana Department of Environmental Quality (DEQ) and 1 site in Lake Pontchartrain near the IHNC were added to the study.

\section{Description of the Study Area}

The MRGO, located in southeastern Louisiana, extends eastward from a turning basin in the IHNC to the confluence with the GIWW near Michoud, La., and then in a southeasterly direction through Breton Sound into the Gulf of Mexico (fig. 1). All reaches of the MRGO were authorized to be $36 \mathrm{feet}$ (ft) deep with a bottom width of $500 \mathrm{ft}$ except in Breton Sound, where it was authorized to be $38 \mathrm{ft}$ deep, with a $600-\mathrm{ft}$ bottom width. Construction of the channel began in March 1958 near the confluence of the IHNC and the GIWW. By July 1963, an interim channel had been completed to the full design depth but only half of the design width, and the first vessel had traveled down the channel. By 1968, all dredging had been completed, and the channel was at the full design dimensions. By 2006, erosion had widened the channel from the original $500 \mathrm{ft}$ to more than 1,500 ft in many places, and shoaling caused by Hurricane Katrina in August 2005 had reduced the channel depth to $22 \mathrm{ft}$ in places, restricting access of deep-draft vessels (U.S. Army Corp of Engineers, 2007; 2010).

The MRGO was originally dredged through shallow bays, coastal marshes, and cypress swamps. The channel changed local and regional hydrologic circulation patterns and allowed saltwater from the Gulf of Mexico to enter wetlands that were dominated by vegetation with a low tolerance to salinity. The MRGO created a direct route for the freshwater held in these wetlands to escape towards estuarine bays and salt marshes. In addition to the direct loss of wetlands caused by the channel construction, the increased salinity exacerbated wetland loss and conversion of freshwater marsh to brackish or saltwater marsh in areas adjacent to the MRGO. The MRGO also altered salinity in Lakes Pontchartrain and Borgne (U.S. Army Corps of Engineers, 2007).

A portion of the MRGO, from the southern edge of the GIWW to the Gulf of Mexico, was deauthorized in 2008. As a result of deauthorization, a rock barrier was placed across the MRGO near mile 35 just south of the Bayou La Loutre Ridge near Hopedale to prevent navigation on an unmaintained channel. Construction of the rock barrier began in February 2009 with the placement of a wide rock base along the channel bottom. The rock barrier first extended above the water surface for the entire channel width on June 4, 2009. The rock barrier, reaching a height of $7 \mathrm{ft}$ above average water level, was completed at the end of July 2009. Details of the deauthorization and closure can be found at http://www. mrgo.gov. 

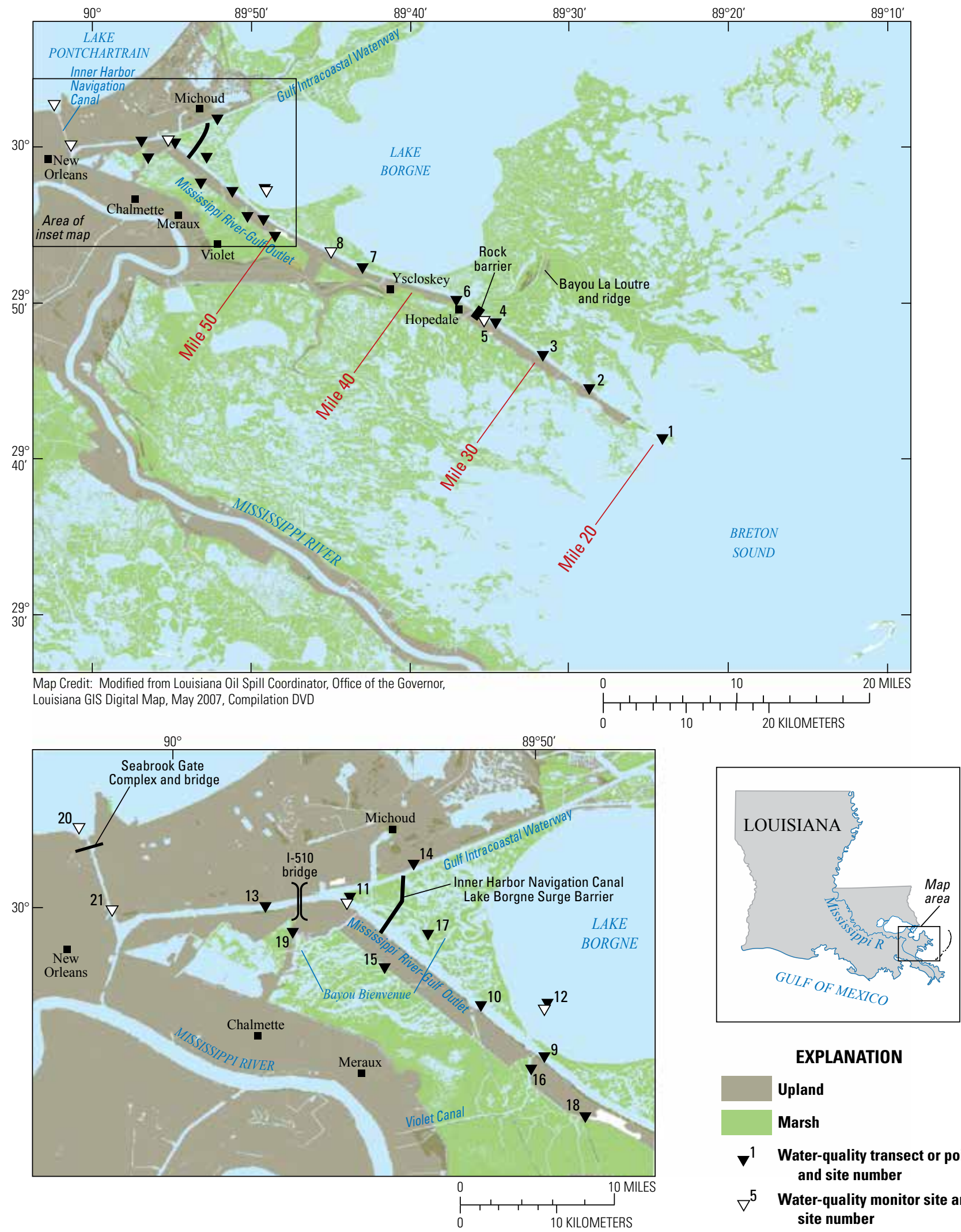

\section{EXPLANATION}

Upland

Marsh

$\nabla^{1}$ Water-quality transect or point and site number

$\nabla^{5} \quad$ Water-quality monitor site and site number

Figure 1. Location of data-collection sites in the Mississippi River-Gulf Outlet and adjacent waterways, southeastern Louisiana. 
To reduce the risk of storm surge in the IHNC, a surge barrier was constructed across the MRGO and GIWW, connecting the MRGO and GIWW hurricane levees (fig. 1). The main pilings for the surge barrier were completed in October 2009 and 6-inch (in.) gaps between pilings were closed by February 11, 2010 (U.S. Army Corps of Engineers, 2012). All segments of the surge barrier wall were in place by September 13, 2010. Floodgates were constructed in the surge barrier at the GIWW and Bayou Bienvenue to permit navigation. A cofferdam was constructed in Bayou Bienvenue during construction of the floodgates, but hydrologic exchange was maintained in the bayou during construction by using flow-through pipes. In addition, the Seabrook floodgates were constructed to prevent entry of surge water from Lake Pontchartrain into the IHNC during a storm. During construction of these floodgates, a cofferdam in the IHNC prevented exchange of water between the IHNC and Lake Pontchartrain. Hydrologic exchange between Lake Pontchartrain and the IHNC ceased on October 31, 2010, and was reestablished in July 2012 (U.S. Army Corps of Engineers, 2012).

\section{Methods}

Discrete and continuous data were collected during this study and stored in the U.S. Geological Survey's National Water Information System (http://waterdata.usgs.gov/nwis). Data collection sites and the types of data-collection activity are listed in table 1. For discrete data, a multiparameter waterquality meter was used to measure specific conductance, $\mathrm{pH}$, temperature, dissolved oxygen (D.O.), and salinity (calculated from specific conductance, Schemel, 2001) at various depths along transects in the MRGO, GIWW, and at selected points in adjacent waterways. Measurements along transects were made at three or five evenly spaced points across the full width of the channel. Channel widths and the distances from the banks were determined by using a laser range finder. Vertical profiles of water quality were measured at three evenly spaced points where the channel was about $900 \mathrm{ft}$ wide and at five evenly spaced points where the channel width was greater than about $900 \mathrm{ft}$. At each point, vertical water-quality profiles were made by taking measurements at every $10 \mathrm{ft}$ of depth starting at $0.5 \mathrm{ft}$ from the channel bottom and ending at $0.5 \mathrm{ft}$ from the water surface. If there was a rapid change in conditions within a 10-ft interval, additional measurements were made every $5 \mathrm{ft}$. The water-quality meter was calibrated for specific conductance, $\mathrm{pH}$, and D.O. on each day prior to data collection; measurements were made following USGS field methods presented in Wilde (variously dated).

Specific conductance, $\mathrm{pH}$, water temperature, D.O., and salinity were measured at seven transects (sites 3, 4, 6, 7, 9,
10, and 11) in the MRGO and at a single point in Lake Borgne (site 12). Regular measurements were made at sites 3 , 4, and 6 from August 2008 to August 2010 and at sites 7, 9, 10, 11, and 12 from August 2008 to October 2012 (fig. 1). Sites 3 and 6 also were sampled in July in 2011 and 2012. Site 4 was sampled in July 2012 as well. Measurements generally were made over 1- or 2-day periods every 4 to 6 weeks from June through October and about every 8 weeks in the intervening time period. Measurements made in August and November 2008 and in January and March 2009 documented conditions before the rock barrier near Hopedale breached the water surface or construction of the surge barrier and the Seabrook floodgates began, when there was still considerable water movement in the MRGO. For this report, concentrations of salinity and D.O. from all vertical profiles along a transect were averaged by depth to create a single vertical profile for each transect for each sampling event. These average values are used herein to represent salinity and D.O. conditions at each transect site.

Hypoxia was documented downstream from the rock barrier at transects near miles 30 (site 3) and 34 (site 4) during June 2009, just as construction was being completed (Swarzenski and others, 2012); consequently, water quality was measured at two additional transects, located farther downstream towards Breton Sound near miles 20 (site 1) and 27 (site 2) (fig. 1), from June 2009 to July 2010 to document the southern extent of hypoxic conditions. These were sampled occasionally, as conditions in the field dictated and time permitted.

In September 2010, sampling downstream from the rock barrier was discontinued after the focus of the waterquality monitoring shifted to the effects of the surge barrier construction. Five stations historically sampled by the DEQ were added. These new stations (sites 15 through 19) were in shallower and narrower waterways, including Bayou Bienvenue and the borrow canal running parallel to and on the landward side of the MRGO levee (fig. 1). At these sites, a single vertical water-quality profile was made in the center of the channel. Two additional transects (sites 13 and 14) were established in the GIWW (fig. 1), on either side of the gated structure being constructed.

Temperature and specific conductance were recorded at 60 - or 120-minute intervals by continuous water-quality meters suspended in the water column at selected monitoring sites. The meters were suspended in stilling wells attached to existing structures or galvanized steel pipes driven into the channel bottom. The stilling wells were constructed of 2-in. polyvinyl chloride (PVC) pipe with 18 in. of perforated copper pipe at the bottom to inhibit the growth of algae on the meters' sensors. The meters were serviced and calibrated during routine site visits by using methods described in Wagner and others (2006). 
Table 1. Data-collection sites in the Mississippi River-Gulf Outlet (MRGO) and adjacent waterways, and in Lake Borgne and Lake Pontchartrain in southeastern Louisiana.

[NAD 27, North American Datum of 1927; Data-collection activity codes: T, water-quality transect; M, water-quality monitor; P, water-quality point; ddmmss is degrees, minutes, and seconds; GIWW, Gulf Intracoastal Waterway]

\begin{tabular}{|c|c|c|c|c|c|c|}
\hline $\begin{array}{c}\text { Site } \\
\text { number } \\
\text { (see fig. 1) }\end{array}$ & $\begin{array}{l}\text { Station } \\
\text { number }\end{array}$ & Station name & $\begin{array}{l}\text { Latitude } \\
\text { ddmmss } \\
\text { (NAD 27) }\end{array}$ & $\begin{array}{l}\text { Longitude } \\
\text { ddmmss } \\
\text { (NAD 27) }\end{array}$ & $\begin{array}{l}\text { Data- } \\
\text { collection } \\
\text { activity } \\
\text { code }\end{array}$ & $\begin{array}{l}\text { Period } \\
\text { sampled }\end{array}$ \\
\hline 1 & 294047089232700 & $\begin{array}{l}\text { MRGO near mile } 20 \text { near } \\
\text { Hopedale }\end{array}$ & 294047 & 892327 & $\mathrm{~T}$ & June 2009-July 2010 \\
\hline 2 & 294414089282400 & $\begin{array}{l}\text { MRGO near mile } 27 \text { near } \\
\text { Hopedale }\end{array}$ & 294414 & 892824 & $\mathrm{~T}$ & June 2009-July 2010 \\
\hline 3 & 294608089310500 & $\begin{array}{l}\text { MRGO near mile } 30 \text { near } \\
\text { Hopedale }\end{array}$ & 294608 & 893105 & $\mathrm{~T}$ & August 2008-July 2012 \\
\hline 4 & 294805089335200 & $\begin{array}{l}\text { MRGO near mile } 34 \text { near } \\
\text { Hopedale }\end{array}$ & 294805 & 893352 & $\mathrm{~T}$ & August 2008-July 2012 \\
\hline 5 & 294900089350800 & $\begin{array}{l}\text { MRGO near mile } 35 \text { near } \\
\text { Hopedale }\end{array}$ & 294900 & 893508 & M & March 2009-September 2010 \\
\hline 7 & 295157089423200 & $\begin{array}{l}\text { MRGO near mile } 44 \text { near } \\
\text { Yscloskey }\end{array}$ & 295157 & 894232 & $\mathrm{~T}$ & August 2008-October 2012 \\
\hline 8 & 295311089445100 & $\begin{array}{l}\text { MRGO near mile } 46 \text { near } \\
\text { Yscloskey }\end{array}$ & 295311 & 894451 & M & January 2009-September 2012 \\
\hline 9 & 295556089494400 & MRGO near mile 52 near Violet & 295556 & 894944 & $\mathrm{~T}$ & August 2008-October 2012 \\
\hline 10 & 295709089511200 & MRGO near mile 54 near Violet & 295709 & 895112 & $\mathrm{~T}$ & August 2008-October 2012 \\
\hline 11 & 300018089551200 & $\begin{array}{l}\text { MRGO near mile } 59 \text { near } \\
\text { Michoud }\end{array}$ & 300108 & 895512 & $\mathrm{~T}, \mathrm{M}$ & August 2008-October 2012 \\
\hline 16 & 295534089502000 & $\begin{array}{l}\text { Violet Canal west of MRGO near } \\
\text { Violet }\end{array}$ & 295534 & 895020 & $P$ & August 2010-October 2012 \\
\hline 17 & 295916089525900 & $\begin{array}{l}\text { Bayou Bienvenue east of MRGO } \\
\text { near Michoud }\end{array}$ & 295916 & 895259 & $\mathrm{P}$ & August 2010-October 2012 \\
\hline 18 & 295434089491100 & $\begin{array}{l}\text { Borrow canal west of MRGO } \\
\text { near Violet }\end{array}$ & 295434 & 894911 & $P$ & August 2010-October 2012 \\
\hline 19 & 295855089564400 & $\begin{array}{l}\text { Bayou Bienvenue at Paris Rd } \\
\text { bridge near Chalmette }\end{array}$ & 295855 & 895644 & $P$ & August 2010-October 2012 \\
\hline 20 & 300156090021100 & $\begin{array}{l}\text { Lake Pontchartrain at Seabrook } \\
\text { bridge }\end{array}$ & 300156 & 900211 & M & August 2010-October 2012 \\
\hline 21 & 738023321 & $\begin{array}{l}\text { Industrial Canal at I-10 at New } \\
\text { Orleans }\end{array}$ & 300016 & 900132 & M & January 2009-October 2012 \\
\hline
\end{tabular}


Six continuous water-quality meters measuring temperature and conductance were deployed at 3 sites in the MRGO near miles 35, 46, and 59 (sites 5, 8, and 11) and 1 site each in Lake Borgne (site 12) and in the IHNC (site 21) in late December 2008 (fig. 1). The meters were suspended at a depth of $6-10 \mathrm{ft}$ below the water surface at sites in the MRGO; at a depth of $4 \mathrm{ft}$ at the site in the IHNC (site 21); and at a depth of $6 \mathrm{ft}$ at the site in Lake Borgne (site 12) near the MRGO. An additional water-quality meter was suspended $20 \mathrm{ft}$ below the water surface at a site in the MRGO near mile 46 (site 8) for evaluation of salinity stratification in the MRGO. In September 2010, the waterquality meter downstream from the rock barrier (site 5) was discontinued. The water-quality meter in the MRGO near mile 46 (site 8) at a depth of $20 \mathrm{ft}$ was discontinued in September 2010. In August 2010, a water-quality meter was placed at the intersection of the IHNC and Lake Pontchartrain, near Seabrook (site 20; fig. 1).

Placement of continuous water-quality meters was primarily limited to existing structures in the channel because of concerns about boat traffic and cost and time constraints on the construction of new data-collection platforms. Existing structures in the MRGO included navigation markers located in relatively shallow water near the sides of the deeper shipping lane. Hence, the maximum depths at which the meters could be placed in the MRGO generally were limited to about $10 \mathrm{ft}$ below the water surface even though the depth of the shipping lane generally ranged from 35 to over $40 \mathrm{ft}$ in most places. During the project, vertical profiles of water quality along these transects provided a more comprehensive indication of channel salinity stratification, whereas the continuous water-quality meters indicated shorter term temporal fluctuations.

\section{Effects of Hydrologic Modifications}

Data on salinity and dissolved oxygen from August 2008 to October 2012 are presented in the following sections to document how the restrictions in water movement caused by the rock barrier, the surge barrier, and the Seabrook floodgates affected salinity and the formation of hypoxia in the MRGO, the GIWW, and other surface waters. Salinity and hypoxia are key parameters affecting habitat quality of estuarine biota. The more than 4 years of sampling measured conditions before, during, and after activities related to the construction and operation of the rock and surge barriers, and the floodgates.

\section{Salinity}

The completion of the rock barrier in July 2009 resulted in the sharp reduction of velocities and discharge upstream and downstream from the barrier in the MRGO (Swarzenski and others, 2012). Prior to completion, salinity measured by the continuous water-quality meter in the MRGO at site 5 downstream from the rock barrier was only moderately higher than salinity at all sites upstream from the barrier as far north as at mile 59, near the junction with the GIWW (fig. 2). Also prior to completion of the rock barrier, fluctuations of 5 or even 10 parts per thousand (ppt) over short time periods were common at sites in the MRGO south of mile 59 (fig. 2). After completion, salinities in the MRGO upstream and downstream from the rock barrier immediately diverged - salinity downstream from the barrier increased rapidly and remained approximately 10 to $20 \mathrm{ppt}$ higher than salinity at sites upstream from the barrier. In addition, short-term salinity fluctuations upstream from the rock barrier became more moderate (fig. 2). The reduction in tidal exchange and hydrologic circulation that resulted from the completion of the rock barrier induced a major shift in salinity patterns in the MRGO.

Completion of the surge barrier in October $2010 \mathrm{did}$ not result in similarly substantial changes to salinity regimes in the MRGO. Salinities in Lake Borgne (site 12) and in the MRGO at mile 46 (site 8) tracked each other closely, with the exception that site 12 had slightly greater fluctuations. Salinities in the MRGO at mile 59 (site 11) and in the IHNC at I-10 (site 21) also tracked each other (fig. 2), though during periods of high salinity in the area, site 21 was usually slightly fresher than site 11. Site 20 in Lake Pontchartrain at the mouth of the IHNC did not record sufficient data for thorough interpretation, but salinity values were similar to values in the IHNC at I-10 (site 21). Salinity in the MRGO at mile 46 (site 8) and in Lake Borgne (site 12) dropped very quickly and steeply in late May and June 2011 and then rebounded quickly as well (fig. 2). This drop coincided with the opening of the Bonnet Carre Spillway, located about 20 miles upstream from New Orleans on the Mississippi River, by the U.S. Army Corps of Engineers between May 9 and June 20, 2011, to ease flooding concerns on the Mississippi River (U.S. Army Corps of Engineers, 2013c). Mississippi River water was released through the Bonnet Carre Spillway into Lake Pontchartrain. Some of the water eventually flowed through the IHNC and other waterways into the GIWW and Lake Borgne. The limited data from site 20 suggested that salinity in the lake at that location was slightly lower than in the IHNC at I-10 (site 21) during the time the cofferdam was built (October 2010-July 2012), a period when hydrologic exchange was limited (fig. 2). 


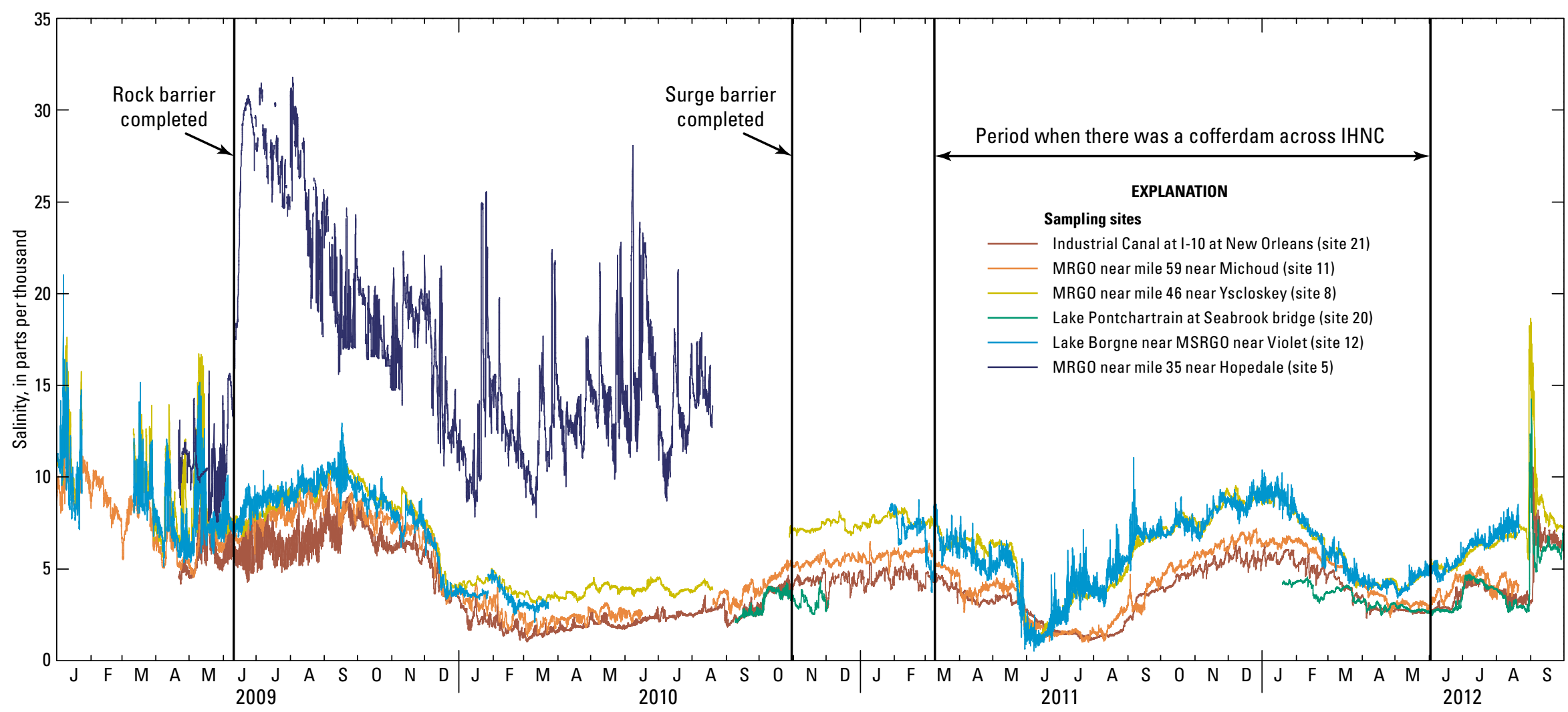

Figure 2. Continuous salinity in the Inner Harbor Navigation (Industrial) Canal (IHNC), the Mississippi River-Gulf Outlet (MRGO), Lake Pontchartrain, and Lake Borgne in southeastern Louisiana, 2009-12. 
Salinity data collected at the transects showed patterns similar to those seen in the continuous data. Figures 3 and 4 show contours of salinity between miles 30 and 59 in the MRGO during midsummer from 2008 to 2012. The effect of the rock barrier is pronounced and is evident in June 2009 even before its completion in July 2009 (table 2). Contours for August 15, 2008, indicate a continuous layer of water with salinities ranging from 18 to $20 \mathrm{ppt}$ extending from mile 30 to mile 59 (fig. 3). This layer occupied the bottom $20 \mathrm{ft}$ of the channel at mile 59 (site 11) and the upper $20 \mathrm{ft}$ of the MRGO at mile 30 (site 3). After completion of the rock barrier, a layer of water of near-equal salinity extending that distance was no longer observed. Salinity downstream from the rock barrier became elevated without the inflow of lower salinity water. Salinity upstream from the rock barrier freshened rapidly once saltwater intrusion was essentially blocked (figs. 3 and 4).

The effects of the surge barrier on salinity in the MRGO were less obvious. Discrete sampling at transect sites indicated that completion of the surge barrier did not result in the divergent salinity regimes at upstream and downstream sites that had resulted after the completion of the rock barrier. Salinity in the MRGO at site 10 at mile 54 may have become slightly more stratified after the surge barrier was completed (figs. 3 and 4); however, there were other factors influencing contour patterns.
The lowest salinities measured at sites both upstream and downstream from the rock barrier were recorded on August 19, 2010 (fig. 3), during the time when controlled diversions of the Mississippi River into coastal estuaries had been maximized to prevent the Deepwater Horizon oil spill from moving upstream into the deltaic wetlands (Louisiana Office of Coastal Protection and Restoration, 2010). Furthermore, there was little stratification of salinity in the MRGO upstream the rock barrier. Salinity in the MRGO upstream and downstream from the rock barrier and the surge barrier differed substantially on July 8, 2011 (fig. 4), unlike on August 19, 2010, when upstream and downstream salinities were more similar (fig. 3). This difference was due in part to influx of freshwater into the upstream reach which resulted from the opening of the Bonnet Carre Spillway during May and June 2011. On July 8, 2011, salinity downstream from the rock barrier was very stratified (fig. 4). Salinity upstream from the rock barrier was moderately stratified and only along the bottom $20 \mathrm{ft}$ of the channel between the barrier and mile 54 (site 10) near the opening to Lake Borgne. Salinity in the uppermost $20 \mathrm{ft}$ of the channel on the upstream side of the rock barrier was fairly homogenous and fresh. Salinity on both sides of the surge barrier in the MRGO was below 2 ppt. 


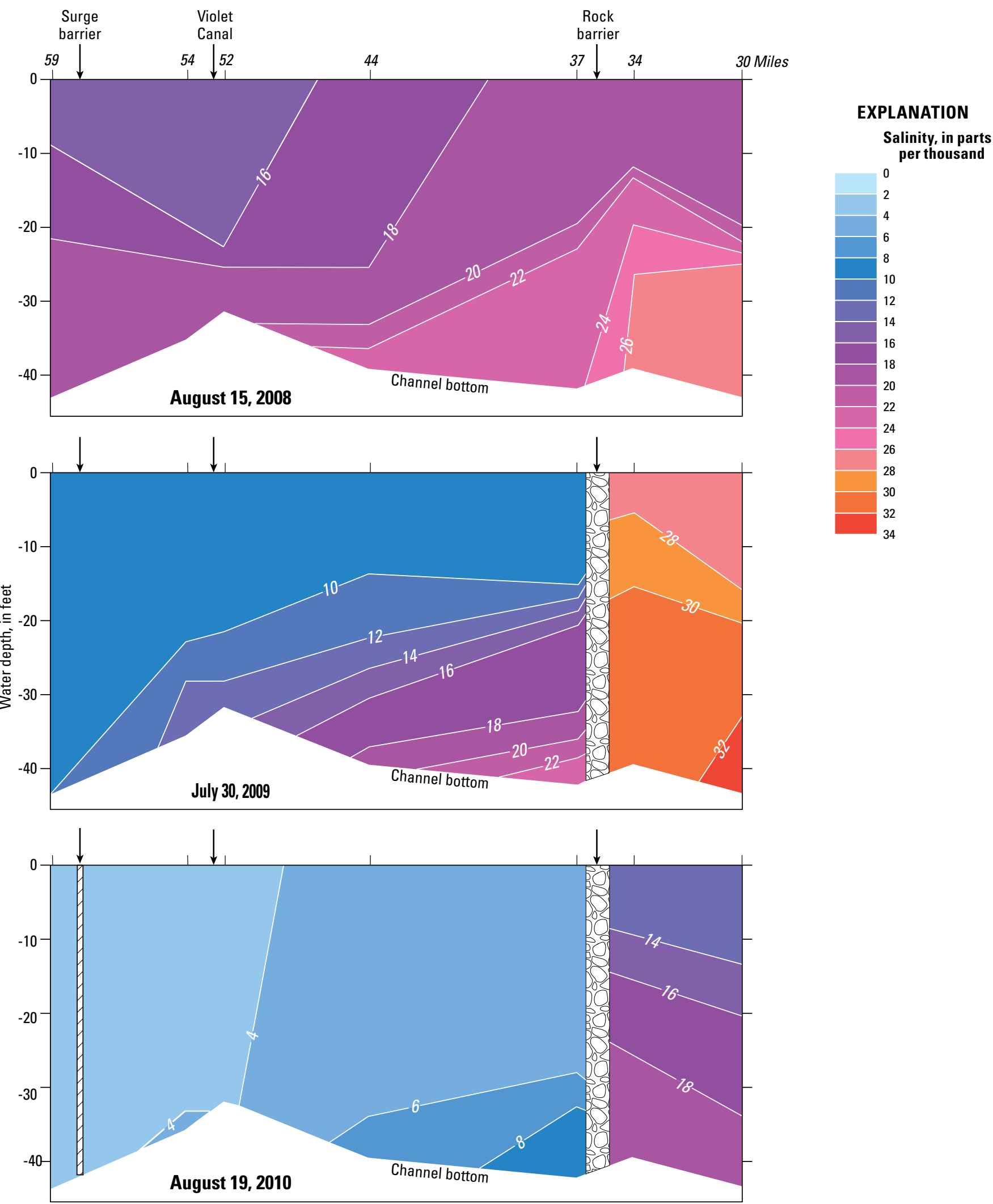

Figure 3. Salinity contours, in parts per thousand, between miles 30 and 59 in the Mississippi River-Gulf Outlet in southeastern Louisiana for August 15, 2008, July 30, 2009, and August 19, 2010. 


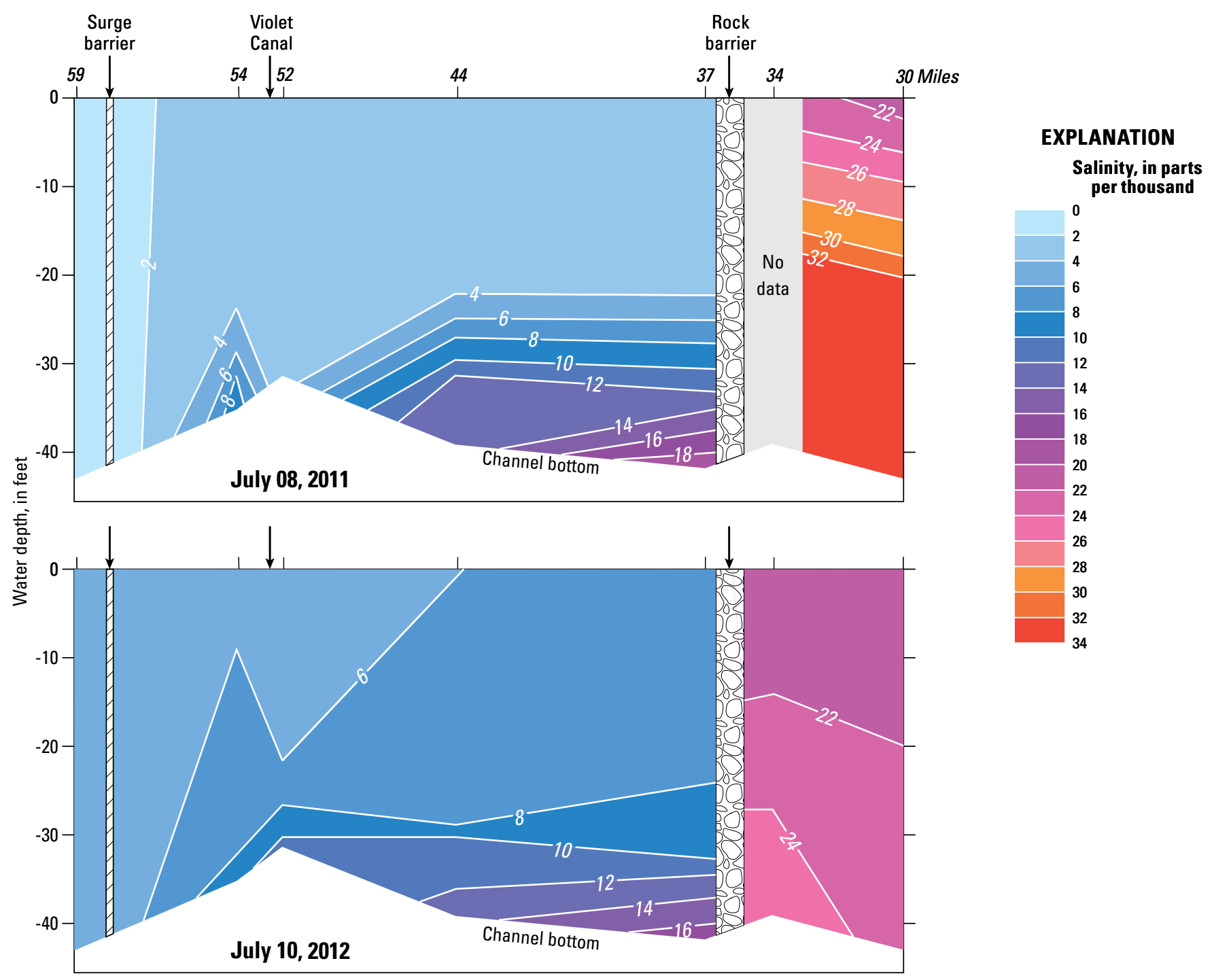

Figure 4. Salinity contours, in parts per thousand, between miles 30 and 59 in the Mississippi River-Gulf Outlet in southeastern Louisiana for July 08, 2011, and July 10, 2012. 
Table 2. Water depth below which dissolved oxygen concentrations are less than 2 milligrams per liter, indicating hypoxic conditions, in the Mississippi River-Gulf Outlet (MRGO) and adjacent surface waters in southeastern Louisiana, August 2008 to October 2012.

[n.d., no data; "none" in green shading indicates no hypoxia in the water column; brown shading indicates hypoxic conditions; GIWW, Gulf Intracoastal Waterway]

\begin{tabular}{|c|c|c|c|c|}
\hline \multirow{2}{*}{$\begin{array}{c}\text { Site } \\
\text { number } \\
\text { (see } \\
\text { fig. 1) }\end{array}$} & \multirow[b]{2}{*}{ Station name } & \multirow{2}{*}{$\begin{array}{c}\text { Maximum } \\
\text { channel } \\
\text { depth } \\
\text { (feet) }\end{array}$} & \multicolumn{2}{|c|}{ Water depth, in feet, below which dissolved oxygen concentrations are less than 2 milligrams per liter } \\
\hline & & & 8/15/2008 & 11/24/2008 \\
\hline 1 & MRGO near mile 20 near Hopedale & 32 & n.d. & n.d. \\
\hline 2 & MRGO near mile 27 near Hopedale & 37 & n.d. & n.d. \\
\hline 3 & MRGO near mile 30 near Hopedale & 40 & none & none \\
\hline 4 & MRGO near mile 34 near Hopedale & 37 & none & none \\
\hline 6 & MRGO near mile 37 near Hopedale & 42 & none & none \\
\hline 7 & MRGO near mile 44 near Yscloskey & 37 & none & none \\
\hline 9 & MRGO near mile 52 near Violet & 34 & none & none \\
\hline 10 & MRGO near mile 54 near Violet & 36 & none & none \\
\hline 11 & MRGO near mile 59 near Michoud & 42 & none & none \\
\hline 12 & Lake Borgne near MRGO near Violet & 8 & none & none \\
\hline 13 & GIWW west of I-510 bridge near Michoud & 40 & none & none \\
\hline 14 & GIWW east of I-510 bridge near Chalmette & 27 & n.d. & n.d. \\
\hline 15 & Borrow canal west of MRGO near Meraux & 5 & n.d. & n.d. \\
\hline 16 & Violet Canal west of MRGO near Violet & 10 & n.d. & n.d. \\
\hline 17 & Bayou Bienvenue east of MRGO near Michoud & 7 & n.d. & n.d. \\
\hline 18 & Borrow canal west of MRGO near Violet & 5 & n.d. & n.d. \\
\hline 19 & Bayou Bienvenue at Paris Rd bridge near Chalmette & 15 & n.d. & n.d. \\
\hline
\end{tabular}


Table 2. Water depth below which dissolved oxygen concentrations are less than 2 milligrams per liter, indicating hypoxic conditions, in the Mississippi River-Gulf Outlet (MRGO) and adjacent surface waters in southeastern Louisiana, August 2008 to October 2012.-Continued

[n.d., no data; "none" in green shading indicates no hypoxia in the water column; brown shading indicates hypoxic conditions; GIWW, Gulf Intracoastal Waterway]

\begin{tabular}{|c|c|c|c|c|c|c|c|c|c|c|}
\hline \multirow{2}{*}{$\begin{array}{c}\text { Site } \\
\text { number } \\
\text { (see } \\
\text { fig. 1) }\end{array}$} & \multirow{2}{*}{ Station name } & \multirow{2}{*}{$\begin{array}{c}\text { Maximum } \\
\text { channel } \\
\text { depth } \\
\text { (feet) }\end{array}$} & \multicolumn{8}{|c|}{ Water depth, in feet, below which dissolved oxygen concentrations are less than $\mathbf{2}$ milligrams per liter } \\
\hline & & & 1/23/2009 & $3 / 1 / 2009$ & $6 / 1 / 2009$ & $6 / 17 / 2009$ & 7/30/2009 & 9/2/2009 & 10/8/2009 & $11 / 13 / 2009$ \\
\hline 1 & MRGO near mile 20 near Hopedale & 32 & n.d. & n.d. & n.d. & 5 & n.d. & n.d. & 15 & n.d. \\
\hline 2 & MRGO near mile 27 near Hopedale & 37 & n.d. & n.d. & n.d. & 5 & 15 & 33 & 27 & n.d. \\
\hline 3 & MRGO near mile 30 near Hopedale & 40 & none & none & 10 & n.d. & 15 & 25 & 23 & none \\
\hline 4 & MRGO near mile 34 near Hopedale & 37 & none & none & 4 & n.d. & 15 & 7 & 27 & none \\
\hline 6 & MRGO near mile 37 near Hopedale & 42 & none & none & 34 & n.d. & 35 & 35 & 37 & 40 \\
\hline 7 & MRGO near mile 44 near Yscloskey & 37 & none & none & 30 & n.d. & 15 & 28 & 27 & none \\
\hline 9 & MRGO near mile 52 near Violet & 34 & none & none & 32 & n.d. & 30 & 31 & 31 & none \\
\hline 10 & MRGO near mile 54 near Violet & 36 & none & none & none & n.d. & none & none & 27 & 35 \\
\hline 11 & MRGO near mile 59 near Michoud & 42 & none & none & 37 & n.d. & none & none & none & none \\
\hline 12 & Lake Borgne near MRGO near Violet & 8 & none & none & none & n.d. & none & none & none & none \\
\hline 13 & GIWW west of I-510 bridge near Michoud & 40 & n.d. & n.d. & n.d. & n.d. & n.d. & n.d. & n.d. & n.d. \\
\hline 14 & GIWW east of I-510 bridge near Chalmette & 27 & n.d. & n.d. & n.d. & n.d. & n.d. & n.d. & n.d. & n.d. \\
\hline 15 & Borrow canal west of MRGO near Meraux & 5 & n.d. & n.d. & n.d. & n.d. & n.d. & n.d. & n.d. & n.d. \\
\hline 16 & Violet Canal west of MRGO near Violet & 10 & n.d. & n.d. & n.d. & n.d. & n.d. & n.d. & n.d. & n.d. \\
\hline 17 & Bayou Bienvenue east of MRGO near Michoud & 7 & n.d. & n.d. & n.d. & n.d. & n.d. & n.d. & n.d. & n.d. \\
\hline 18 & Borrow canal west of MRGO near Violet & 5 & n.d. & n.d. & n.d. & n.d. & n.d. & n.d. & n.d. & n.d. \\
\hline 19 & Bayou Bienvenue at Paris Rd bridge near Chalmette & 15 & n.d. & n.d. & n.d. & n.d. & n.d. & n.d. & n.d. & n.d. \\
\hline
\end{tabular}


Table 2. Water depth below which dissolved oxygen concentrations are less than 2 milligrams per liter, indicating hypoxic conditions, in the Mississippi River-Gulf Outlet (MRGO) and adjacent surface waters in southeastern Louisiana, August 2008 to October 2012.-Continued

[n.d., no data; "none" in green shading indicates no hypoxia in the water column; brown shading indicates hypoxic conditions; GIWW, Gulf Intracoastal Waterway]

\begin{tabular}{|c|c|c|c|c|c|c|c|c|c|c|}
\hline \multirow{2}{*}{$\begin{array}{c}\text { Site } \\
\text { number } \\
\text { (see } \\
\text { fig. 1) }\end{array}$} & \multirow{2}{*}{ Station name } & \multirow{2}{*}{$\begin{array}{c}\text { Maximum } \\
\text { channel } \\
\text { depth } \\
\text { (feet) }\end{array}$} & \multicolumn{8}{|c|}{ Water depth, in feet, below which dissolved oxygen concentrations are less than 2 milligrams per liter } \\
\hline & & & 2/13/2010 & $3 / 24 / 2010$ & 5/17/2010 & 6/16/2010 & $7 / 22 / 2010$ & 8/19/2010 & 9/9/2010 & 10/28/2010 \\
\hline 1 & MRGO near mile 20 near Hopedale & 32 & n.d. & n.d. & 30 & n.d. & 15 & n.d. & n.d. & n.d. \\
\hline 2 & MRGO near mile 27 near Hopedale & 37 & n.d. & n.d. & none & n.d. & 25 & n.d. & n.d. & n.d. \\
\hline 3 & MRGO near mile 30 near Hopedale & 40 & none & none & 27 & 5 & 22 & 13 & n.d. & n.d. \\
\hline 4 & MRGO near mile 34 near Hopedale & 37 & 36 & none & 27 & 5 & 25 & 8 & n.d. & none \\
\hline 6 & MRGO near mile 37 near Hopedale & 42 & none & 40 & 37 & n.d. & 30 & 35 & n.d. & 38 \\
\hline 7 & MRGO near mile 44 near Yscloskey & 37 & none & none & 27 & 33 & 30 & 28 & n.d. & none \\
\hline 9 & MRGO near mile 52 near Violet & 34 & none & none & none & 28 & n.d. & none & none & none \\
\hline 10 & MRGO near mile 54 near Violet & 36 & none & 35 & 31 & none & none & 33 & none & none \\
\hline 11 & MRGO near mile 59 near Michoud & 42 & none & none & none & none & none & none & none & none \\
\hline 12 & Lake Borgne near MRGO near Violet & 8 & none & none & none & none & none & none & none & none \\
\hline 13 & GIWW west of I-510 bridge near Michoud & 40 & n.d. & n.d. & n.d. & 33 & none & 27 & n.d. & none \\
\hline 14 & GIWW east of I-510 bridge near Chalmette & 27 & n.d. & n.d. & n.d. & n.d. & n.d. & none & none & none \\
\hline 15 & Borrow canal west of MRGO near Meraux & 5 & n.d. & n.d. & n.d. & n.d. & n.d. & none & none & none \\
\hline 16 & Violet Canal west of MRGO near Violet & 10 & n.d. & n.d. & n.d. & n.d. & n.d. & none & 7 & none \\
\hline 17 & Bayou Bienvenue east of MRGO near Michoud & 7 & n.d. & n.d. & n.d. & n.d. & n.d. & none & none & none \\
\hline 18 & Borrow canal west of MRGO near Violet & 5 & n.d. & n.d. & n.d. & n.d. & n.d. & none & none & none \\
\hline 19 & Bayou Bienvenue at Paris Rd bridge near Chalmette & 15 & n.d. & n.d. & n.d. & n.d. & n.d. & none & none & none \\
\hline
\end{tabular}


Table 2. Water depth below which dissolved oxygen concentrations are less than 2 milligrams per liter, indicating hypoxic conditions, in the Mississippi River-Gulf Outlet (MRGO) and adjacent surface waters in southeastern Louisiana, August 2008 to October 2012.-Continued

[n.d., no data; "none" in green shading indicates no hypoxia in the water column; brown shading indicates hypoxic conditions; GIWW, Gulf Intracoastal Waterway]

\begin{tabular}{|c|c|c|c|c|c|c|c|c|c|c|c|}
\hline \multirow{2}{*}{$\begin{array}{c}\text { Site } \\
\text { number } \\
\text { (see } \\
\text { fig. 1) }\end{array}$} & \multirow[b]{2}{*}{ Station name } & \multirow{2}{*}{$\begin{array}{c}\text { Maximum } \\
\text { channel } \\
\text { depth } \\
\text { (feet) }\end{array}$} & \multicolumn{9}{|c|}{ Water depth, in feet, below which dissolved oxygen concentrations are less than 2 milligrams per liter } \\
\hline & & & $1 / 22 / 2011$ & $3 / 31 / 2011$ & $5 / 9 / 2011$ & 6/23/2011 & 7/8/2011 & 8/12/2011 & 9/20/2011 & 10/13/2011 & 12/19/2011 \\
\hline 1 & MRGO near mile 20 near Hopedale & 32 & n.d. & n.d. & n.d. & n.d. & n.d. & n.d. & n.d. & n.d. & n.d. \\
\hline 2 & MRGO near mile 27 near Hopedale & 37 & n.d. & n.d. & n.d. & n.d. & n.d. & n.d. & n.d. & n.d. & n.d. \\
\hline 3 & MRGO near mile 30 near Hopedale & 40 & n.d. & n.d. & none & n.d. & 5 & n.d. & n.d. & none & n.d. \\
\hline 4 & MRGO near mile 34 near Hopedale & 37 & n.d. & 33 & 35 & n.d. & n.d. & n.d. & n.d. & none & n.d. \\
\hline 6 & MRGO near mile 37 near Hopedale & 42 & none & 35 & none & n.d. & 34 & n.d. & n.d. & n.d. & n.d. \\
\hline 7 & MRGO near mile 44 near Yscloskey & 37 & none & 33 & none & 30 & 25 & 27 & 27 & none & none \\
\hline 9 & MRGO near mile 52 near Violet & 34 & none & 28 & none & n.d. & 23 & 27 & 27 & none & none \\
\hline 10 & MRGO near mile 54 near Violet & 36 & none & 32 & none & n.d. & 25 & 23 & 27 & none & none \\
\hline 11 & MRGO near mile 59 near Michoud & 42 & none & none & none & none & 33 & none & none & none & none \\
\hline 12 & Lake Borgne near MRGO near Violet & 8 & none & none & none & none & none & none & none & none & none \\
\hline 13 & GIWW west of I-510 bridge near Michoud & 40 & none & none & none & n.d. & 37 & none & 32 & none & none \\
\hline 14 & GIWW east of I-510 bridge near Chalmette & 27 & none & none & none & none & none & none & none & none & none \\
\hline 15 & Borrow canal west of MRGO near Meraux & 5 & none & none & none & none & none & none & none & none & none \\
\hline 16 & Violet Canal west of MRGO near Violet & 10 & none & none & none & none & none & none & none & none & none \\
\hline 17 & Bayou Bienvenue east of MRGO near Michoud & 7 & none & none & none & none & none & none & none & 3 & none \\
\hline 18 & Borrow canal west of MRGO near Violet & 5 & none & none & none & none & none & 2 & none & none & none \\
\hline 19 & Bayou Bienvenue at Paris Rd bridge near Chalmette & 15 & none & none & none & none & none & none & none & none & none \\
\hline
\end{tabular}


Table 2. Water depth below which dissolved oxygen concentrations are less than 2 milligrams per liter, indicating hypoxic conditions, in the Mississippi River-Gulf Outlet (MRGO) and adjacent surface waters in southeastern Louisiana, August 2008 to October 2012.-Continued

[n.d., no data; "none" in green shading indicates no hypoxia in the water column; brown shading indicates hypoxic conditions; GIWW, Gulf Intracoastal Waterway]

\begin{tabular}{|c|c|c|c|c|c|c|c|c|}
\hline \multirow{2}{*}{$\begin{array}{c}\text { Site } \\
\text { number } \\
\text { (see } \\
\text { fig. 1) }\end{array}$} & \multirow[b]{2}{*}{ Station name } & \multirow{2}{*}{$\begin{array}{c}\text { Maximum } \\
\text { channel } \\
\text { depth } \\
\text { (feet) }\end{array}$} & \multicolumn{6}{|c|}{ Water depth, in feet, below which dissolved oxygen concentrations are less than 2 milligrams per liter } \\
\hline & & & 3/8/2012 & 5/11/2012 & 6/15/2012 & 7/10/2012 & 8/21/2012 & 10/4/2012 \\
\hline 1 & MRGO near mile 20 near Hopedale & 32 & n.d. & n.d. & n.d. & n.d. & n.d. & n.d. \\
\hline 2 & MRGO near mile 27 near Hopedale & 37 & n.d. & n.d. & n.d. & n.d. & n.d. & n.d. \\
\hline 3 & MRGO near mile 30 near Hopedale & 40 & n.d. & n.d. & n.d. & 12 & n.d. & n.d. \\
\hline 4 & MRGO near mile 34 near Hopedale & 37 & n.d. & n.d. & n.d. & 5 & n.d. & n.d. \\
\hline 6 & MRGO near mile 37 near Hopedale & 42 & n.d. & n.d. & n.d. & 38 & n.d. & n.d. \\
\hline 7 & MRGO near mile 44 near Yscloskey & 37 & none & 30 & 32 & 28 & 22 & none \\
\hline 9 & MRGO near mile 52 near Violet & 34 & none & n.d. & none & 28 & 33 & none \\
\hline 10 & MRGO near mile 54 near Violet & 36 & none & none & none & 28 & 35 & none \\
\hline 11 & MRGO near mile 59 near Michoud & 42 & none & n.d. & none & none & none & none \\
\hline 12 & Lake Borgne near MRGO near Violet & 8 & none & none & none & none & none & none \\
\hline 13 & GIWW west of I-510 bridge near Michoud & 40 & none & none & none & none & none & none \\
\hline 14 & GIWW east of I-510 bridge near Chalmette & 27 & none & none & none & none & none & none \\
\hline 15 & Borrow canal west of MRGO near Meraux & 5 & none & none & none & none & none & none \\
\hline 16 & Violet Canal west of MRGO near Violet & 10 & none & none & none & none & 5 & none \\
\hline 17 & Bayou Bienvenue east of MRGO near Michoud & 7 & none & none & none & none & none & none \\
\hline 18 & Borrow canal west of MRGO near Violet & 5 & none & none & 2 & none & none & none \\
\hline 19 & Bayou Bienvenue at Paris Rd bridge near Chalmette & 15 & none & none & none & none & none & none \\
\hline
\end{tabular}




\section{Hypoxia Formation}

In every year of sampling following completion of the rock barrier in 2009, many parts of the MRGO became hypoxic for some or most of the channel depth during summer months. Hypoxia generally was more severe in the section of the MRGO downstream from the rock barrier. Hypoxia was not found in the MRGO during any of the four preconstruction sampling events, but preconstruction sampling was limited to the 10 months prior to the rock barrier completion and included only one event during a summer month, the time period when hypoxia generally was observed after construction. If hypoxia occurred in the MRGO prior to completion of the rock barrier, it was most likely of limited extent and duration because of the strong daily tidal exchange which moved water throughout the MRGO (Swarzenski and others, 2012). Completion of the surge barrier did not contribute to the new formation of extensive hypoxia in the MRGO or adjacent surface waters.

Hypoxia was first measured in the MRGO in June 2009 (table 2). On occasion, hypoxia extended to within 5-10 ft of the channel surface for at least $16 \mathrm{mi}$ downstream from the rock barrier, the farthest point sampled in this study. A hypoxic zone frequently extended upstream from the rock barrier to mile 52 (site 9). Hypoxia developed mainly along the bottom 5-15 ft. The most extensive hypoxia measured in the MRGO was on October 8, 2009, when it extended from mile 20 (site 1) to mile 54 (site 10) (fig. 5). This was the only year that hypoxic conditions were extensively documented in the MRGO as late as October. From 2010 to 2012, hypoxia generally formed from May to September (table 2), but in 2011, extensive hypoxia was found in March and again starting in July, but not in May and June.

When a hypoxic zone was observed in the MRGO, the horizontal and vertical extent of the zone was typically greater downstream from the rock barrier than it was upstream. This pattern appeared to be linked to the potential for lateral hydraulic exchange with adjacent surface waters. Downstream from the barrier, hydraulic gradients can push water in a northwesterly direction in the MRGO and trap the water against the rock barrier. The fairly contiguous marshes and spoil banks lining the MRGO inhibit the movement and exchange of water between the MRGO and surrounding surface waters. Upstream from the rock barrier, there are several lateral openings along the MRGO to adjacent surface waters, including Bayou La Loutre, Lake Borgne, and the GIWW, which could allow easier water circulation and reduce the occurrence of hypoxia in the MRGO upstream from the rock barrier.

Vertical profiles of salinity and D.O. at transect sites in the MRGO and the GIWW were plotted for summer months of 2010, 2011, and 2012 to more closely examine the role of the surge barrier and the cofferdam on the development of hypoxia in surrounding surface waters (figs. 6-8). Transect sites in the MRGO at mile 54 (site 10, downstream from the surge barrier), at mile 59 (site 11, upstream from the surge barrier), and in the GIWW (site 13, west of the I-510 bridge) were used.

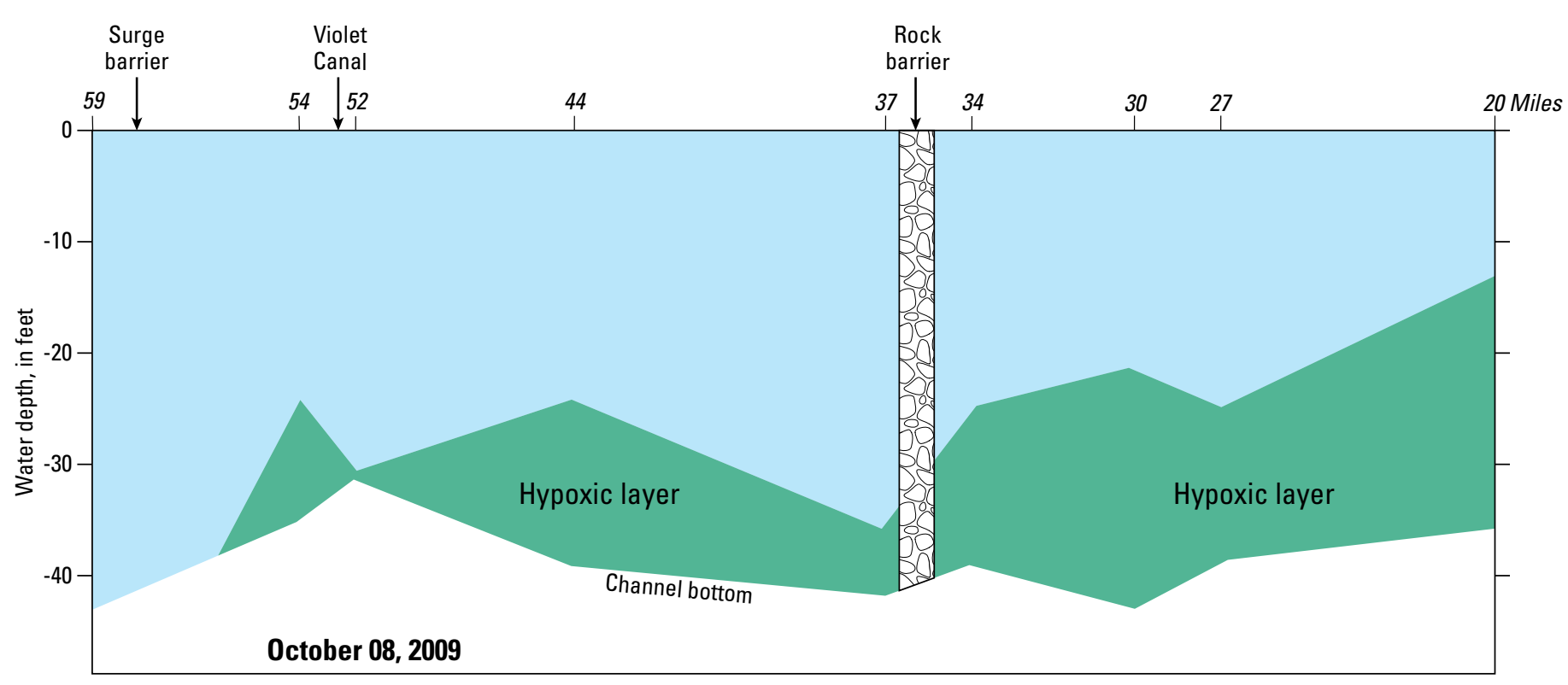

Figure 5. Extent of hypoxic layer, between miles 20 and 59 in the Mississippi River-Gulf Outlet in southeastern Louisiana on 0 ctober 8 , 2009; hypoxia occurs when dissolved oxygen concentrations are less than 2 milligrams per liter. 

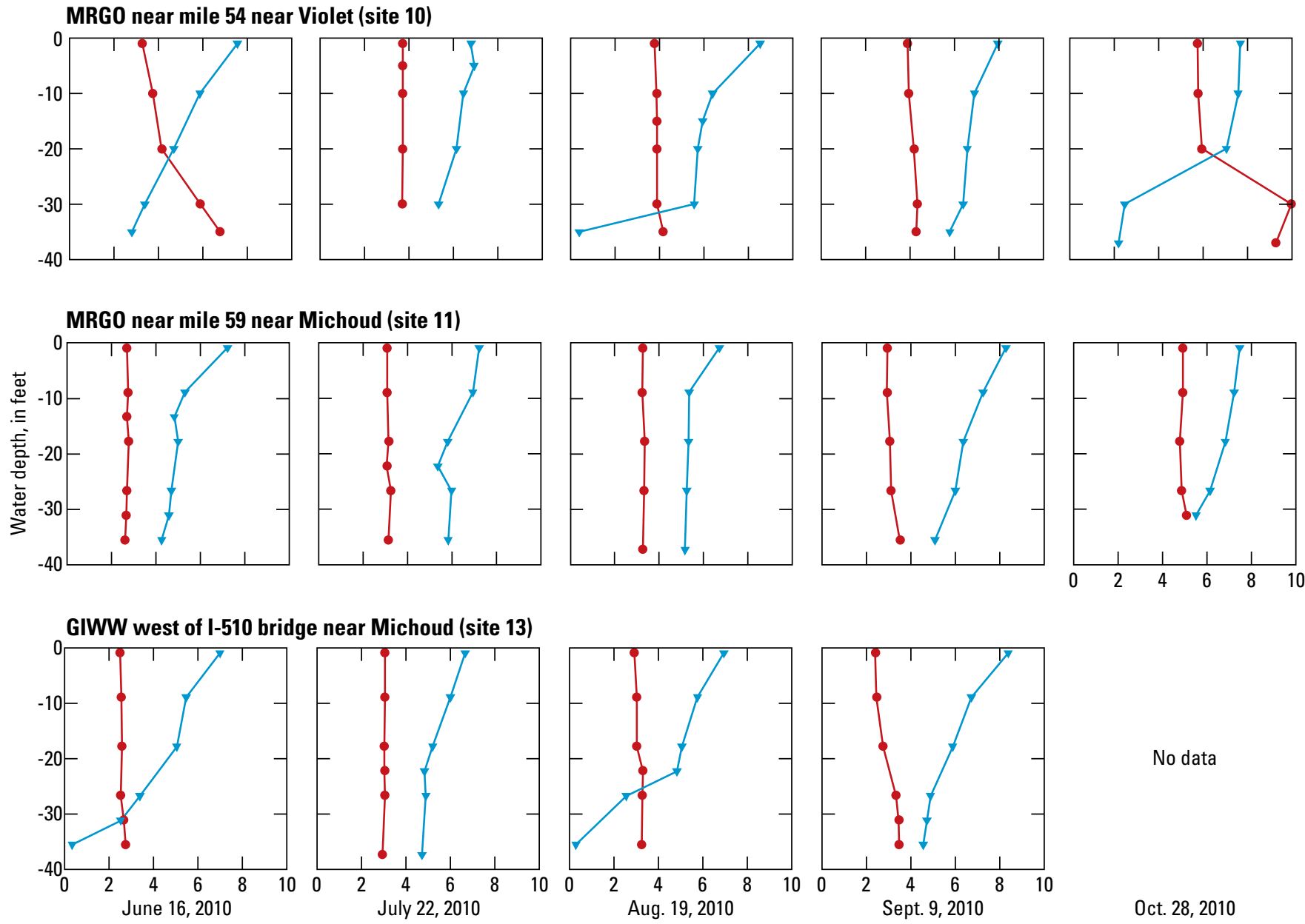

No data

EXPLANATION

Salinity, in parts per thousand, or dissolved oxygen, in milligrams per liter

$\longrightarrow$ Salinity

$\longrightarrow$ Dissolved oxygen

Figure 6. Vertical profiles of salinity and dissolved oxygen at transects in the Mississippi River-Gulf Outlet (MRGO) and the Gulf Intracoastal Waterway (GIWW) in southeastern Louisiana, June to October 2010.

Vertical profiles of salinity at all three transect sites generally were fairly uniform during 2010 and ranged from 2 to 5 ppt. In 2010, hypoxia was measured along the very bottom of the channel on August 19 in the MRGO near mile 54 (site 10), downstream from the surge barrier. Surprisingly, salinity on this date did not show much stratification. On June 16 and October 28, 2010, D.O. concentrations dropped to near hypoxic conditions in the MRGO near mile 54 (site 10). For these times, salinity was higher along the bottom. In the GIWW west of the I-510 bridge (site 13), hypoxia was found along the channel bottom both on June 16 and August 19, 2010. In 2011, hypoxia was found at the channel bottom in the MRGO near mile 54 (site 10) in the July, August, and September sampling. Salinity at this site increased near the bottom, and markedly so for the 3 months when hypoxia was found. Upstream from the surge barrier, vertical salinity profiles were more uniform. Hypoxia also was found along the channel bottom in the MRGO at mile 59 (site 11) and in the GIWW west of the I-510 bridge (site 13) on July 8, 2011, and at the latter site again on September 20, 2011. In 2012, hypoxia was measured only downstream from the surge barrier, in the MRGO at mile 54 (site 10). This finding occurred on July 10 and August 21, when there was an increase in salinity along the channel bottom.

The surge barrier may have contributed to localized hypoxia formation. Once the barrier was in place, water movement in the MRGO between the GIWW and the opening to Lake Borgne was further reduced. This reduction in water 
MRGO near mile 54 near Violet (site 10)
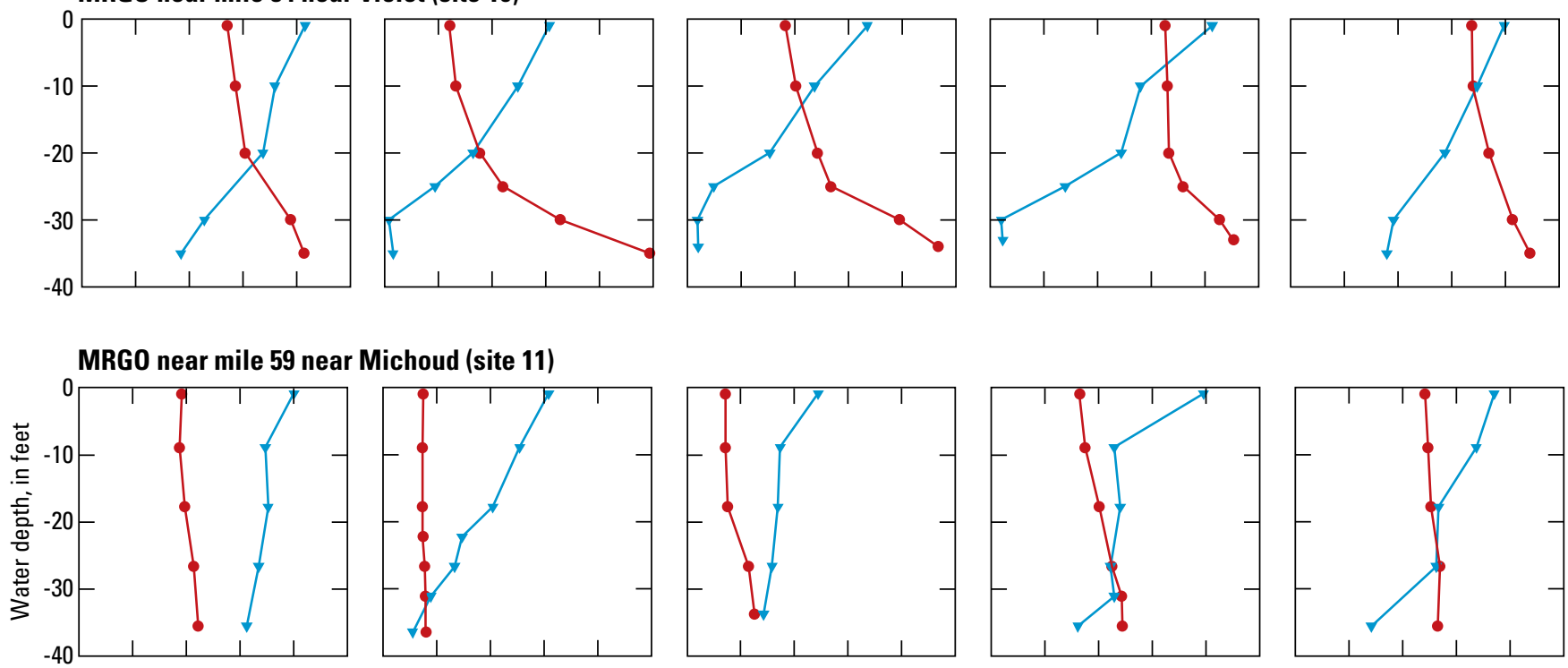

GIWW west of I-510 bridge near Michoud (site 13)
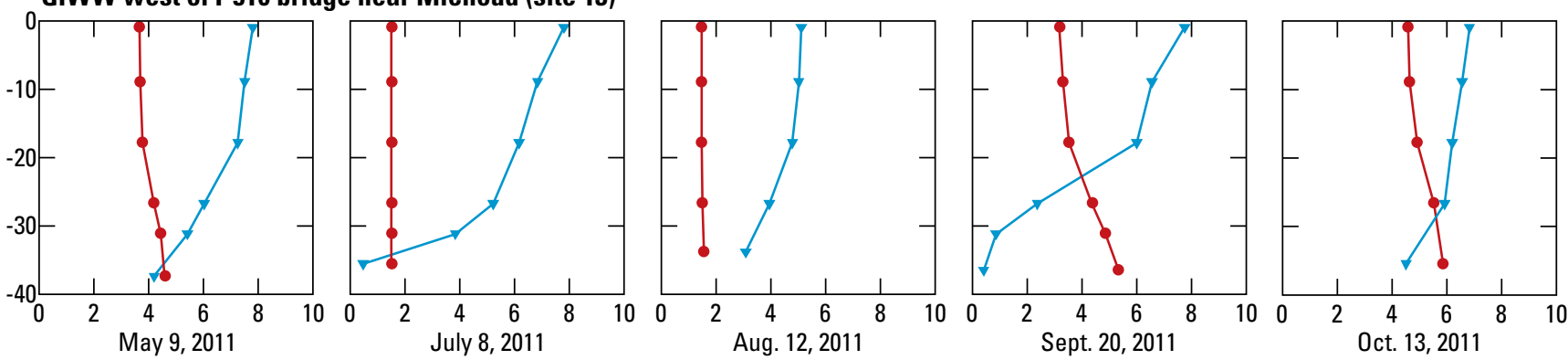

EXPLANATION

Salinity, in parts per thousand, or dissolved oxygen, in milligrams per liter

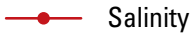

$\longrightarrow$ Dissolved oxygen

Figure 7. Vertical profiles of salinity and dissolved oxygen at transects in the Mississippi River-Gulf Outlet (MRGO) and the Gulf Intracoastal Waterway (GIWW) in southeastern Louisiana, May to October 2011.

movement could allow higher salinity water to enter from the opening to Lake Borgne and move along the bottom northward in the MRGO, which could establish salinity stratification and eventually result in hypoxic conditions forming near mile 54 (site 10). Upstream from the surge barrier, hypoxia appeared to have formed temporarily, possibly in response to the blocking of hydrologic exchange between Lake Pontchartrain and the GIWW that ended in 2012.

In the waterways adjacent to the MRGO and the GIWW, conditions became hypoxic only once, at a site on Bayou Bienvenue (site 17), on the flood side of the surge barrier on October 13, 2011 (table 2). No other site in or adjacent to the MRGO and the GIWW showed hypoxia on this date. On the inside (sites 15, 16, 18, and 19) of the MRGO flood control levee, hypoxia formed several times but never more than at one site per unique sampling date (table 2).

Factors that contributed the most to development of hypoxia in the MRGO likely were the reduction of hydrologic circulation and tidal exchange in the MRGO upon completion of the rock barrier (Swarzenski and others, 2012) and to a lesser extent the surge barrier, and the depth of the MRGO, which was 10 to $30 \mathrm{ft}$ deeper than surrounding water bodies. These conditions effectively created areas with minimal water movement that were conducive to stratification of salinity, reduced vertical mixing, and likely facilitated development of hypoxic conditions. Hypoxia primarily formed during the summer months when high water temperatures lower the oxygen-holding capacity of water. 
MRG0 near mile 54 near Violet (site 10)
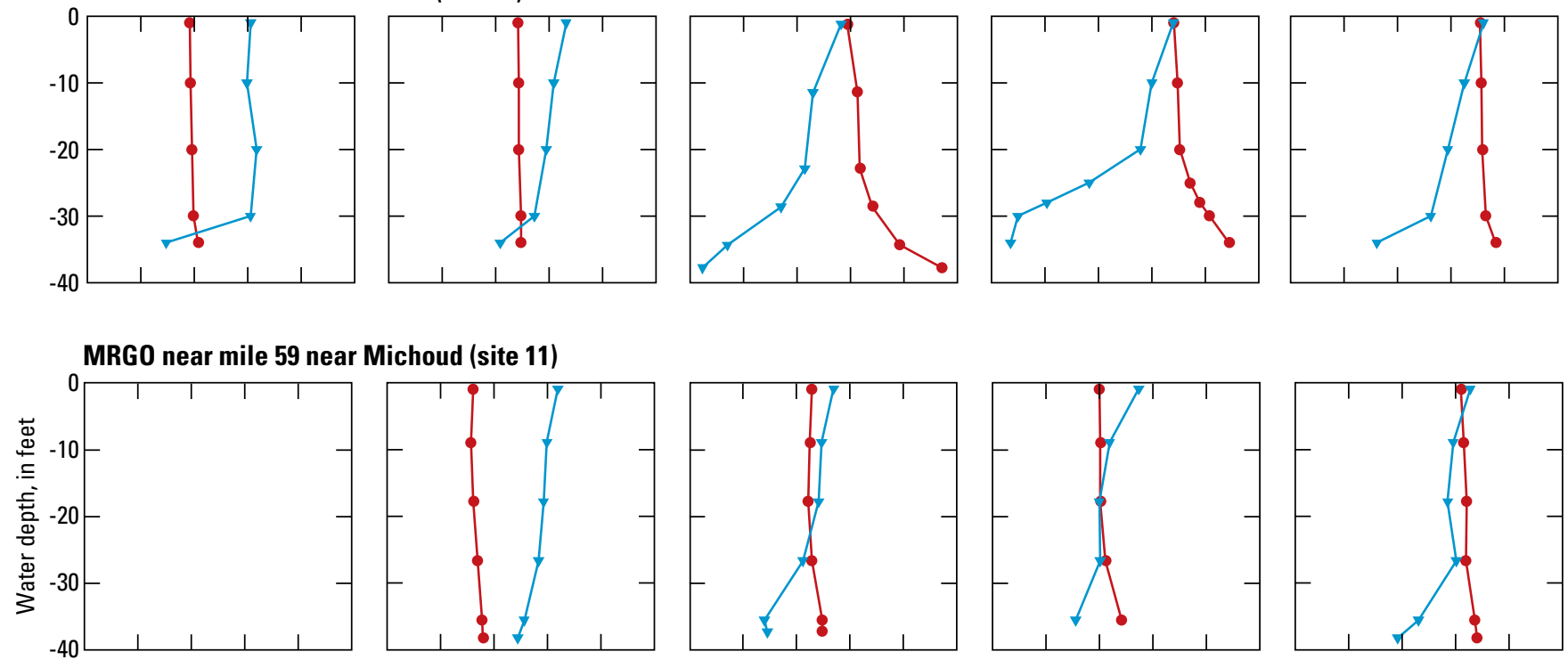

GIWW west of I-510 bridge near Michoud (site 13)
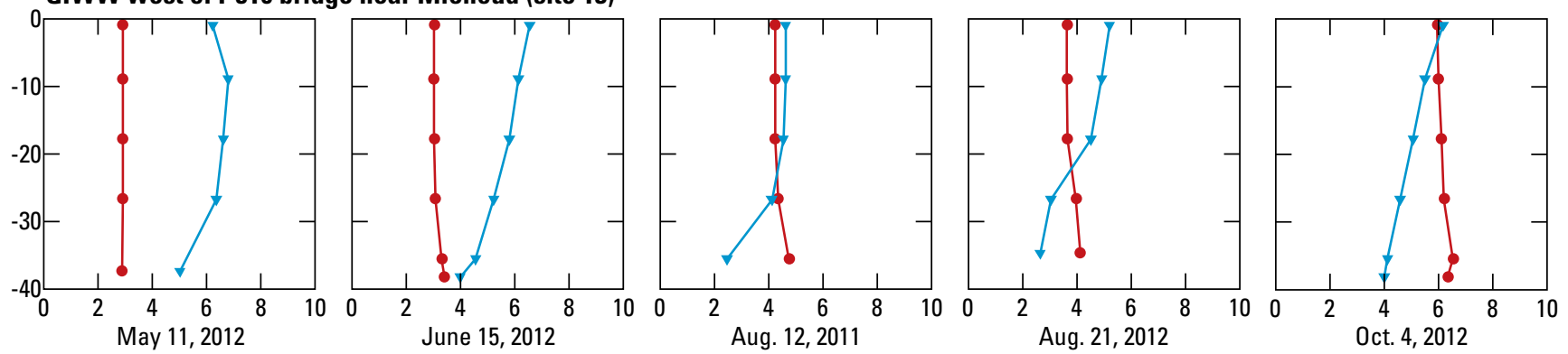

EXPLANATION

Salinity, in parts per thousand, or dissolved oxygen, in milligrams per liter

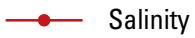

$\longrightarrow$ Dissolved oxygen

Figure 8. Vertical profiles of salinity and dissolved oxygen at transects in the Mississippi River-Gulf Outlet (MRGO) and the Gulf Intracoastal Waterway (GIWW) in southeastern Louisiana, May to October 2012.

In contrast, hypoxic events in the shallow, low-flow bayous surrounding the MRGO and the GIWW were localized and occurred in isolated episodes independent of construction activities on MRGO. Hypoxia in these waterways can result from nonpoint source pollution, for example through organic and nutrient enrichment after rainfall events. Two construction activities proposed for environmental mitigation of the MRGO impacts (U.S. Army Corps of Engineers, 2011) may affect salinity and the occurrence and severity of hypoxic conditions in the MRGO and adjacent waterways in the future.
A proposed controlled diversion of Mississippi River water near Meraux, La., and Violet Canal will have to cross the MRGO to reach its target wetlands to the east. New patterns of hydrologic circulation and salinity will result. Restoration of wetlands affected by the construction of the MRGO also calls for extensive excavation of borrow material from the bottom at various locations in Lake Borgne, to be used to armor wetland shorelines. This excavation of bottom material will create pits with reduced hydrologic circulation that could increase the prevalence of localized hypoxia. 


\section{Summary}

The Mississippi River-Gulf Outlet (MRGO) was constructed between 1958 and 1968 to provide a safer and shorter route between the Gulf of Mexico and the Port of New Orleans for ocean-going vessels. In 2006, the U.S. Congress directed the U.S. Army Corps of Engineers (USACE) to develop and implement a plan to deauthorize a portion of the MRGO ship channel from its confluence with the Gulf Intracoastal Waterway to the Gulf of Mexico. In 2009, in accordance with plans submitted to Congress, the USACE built a rock barrier across the MRGO near Hopedale, Louisiana. Following Hurricane Katrina, Congress also authorized the USACE to implement the Hurricane Storm Damage Risk Reduction System (HSDRRS) by building structures in the MRGO and adjacent surface waters, to reduce vulnerability of this area to storm surge. The HSDRRS included a Gulf Intracoastal Waterway-Lake Borgne surge barrier near mile 58 of the MRGO and a Seabrook Gate Complex on the IHNC. Construction of these structures affected hydrologic circulation in the MRGO and in adjacent waterways, in some locations permanently and in others temporarily. In 2008, the U.S. Geological Survey, in cooperation with the USACE, began a study to document the effects of the construction activities on salinity and dissolved oxygen in these surface waters. Data were collected from August 2008 through October 2012.

Of all the modifications made to the MRGO and adjacent waterways because of deauthorization and flood control, completion of the rock barrier near mile 35 had by far the most effect on salinity and formation of hypoxia in surface waters in the study area. The rock barrier, which was completed in July 2009, restricted tidal exchange in the MRGO and divided the MRGO into an upstream section with lower salinity and a downstream section, open to Breton Sound and the Gulf of Mexico, with higher salinity. Rapid and large salinity fluctuations in much of the MRGO were typical before the barrier was completed. These fluctuations were dampened along most of the MRGO and even in Lake Borgne after completion of the rock barrier. The continuous salinity data indicated that stations Lake Borgne near MRGO (site 12) and MRGO near mile 46 (site 8) responded more quickly to the opening of the Bonnet Carre Spillway in 2011 (going from more saline to fresher conditions), but also reverted to more saline conditions faster than stations Industrial Canal at I-10 (site 21) and MRGO near mile 59 (site 11).

The completion of the rock barrier also contributed to the formation of hypoxic conditions in a large part of the MRGO during summer months when water temperatures were high. Hypoxic conditions extended throughout much of the water column downstream from the rock barrier, but upstream from the barrier, hypoxic conditions generally only occurred in the bottom half of the channel or just near the bottom. The most extensive hypoxic zone was measured in October 2009 when it extended at least 34 miles in the MRGO, from mile 20 to mile 54. Similarly large shifts in salinity regimes or formation of extensive hypoxia did not occur once the surge barrier was completed nor during construction activities related to the construction of floodgates, which also restricted hydrologic exchange even if only temporarily.

The factors that contributed the most to hypoxia in the MRGO were the reductions in tidal water movement there after completion of the rock barrier combined with the channel depth in the MRGO, which is 10 to $30 \mathrm{ft}$ deeper in places than surrounding surface water bodies. These factors helped to stratify salinity by reducing vertical mixing in the water column.

\section{References Cited}

Coastal Protection and Restoration Authority of Louisiana, 2007, Integrated ecosystem restoration and hurricane protection-Louisiana's 2007 comprehensive master plan for a sustainable coast: Baton Rouge, La., Louisiana Department of Natural Resources, accessed April 8, 2014, at http://sonris-www.dnr.state.la.us/dnrservices/redirectUrl. jsp?dID=4063376.

Committee on Environment and Natural Resources, 2003, An assessment of coastal hypoxia and eutrophication in U.S. waters: Washington, D.C., National Science and Technology Council Committee on Environment and Natural Resources, 74 p., accessed April 29, 2014, at http://oceanservice.noaa.gov/outreach/pdfs/coastalhypoxia. pdf.

Louisiana Office of Coastal Protection and Restoration, 2010, Officials open Davis Pond Diversion to full capacity to help curb oil penetration into coastal marshes: press release, accessed November 20, 2013, at http://emergency.louisiana. gov/Releases/05102010-ocpr.html.

Microsoft Bing Maps, 2010, Bing Maps aerial imagery: Redmond, Wash., Microsoft Corporation.

Schemel, L.E., 2001, Simplified conversions between specific conductance and salinity units for use with data from monitoring stations: IEP [Interagency Ecological Program for the San Francisco Bay Estuary] Newsletter, v. 14, no. 1, p. 17-18, accessed May 21, 2014, at http://sfbay.wr.usgs. gov/publications/pdf/schemel_2001_conversions.pdf.

Swarzenski, C.M., Mize, S.V., and Lovelace, J.K., 2012, Water-quality, bed-sediment, and discharge data for the Mississippi River-Gulf Outlet and adjacent waterways, southeastern Louisiana, August 2008 through December 2009: U.S. Geological Survey Open-File Report 2012$1056,52 \mathrm{p}$. 
U.S. Army Corps of Engineers, 2007, Integrated final report to Congress and legislative environmental impact statement for the Mississippi River-Gulf Outlet deep-draft de-authorization study, v. 1, main report: U.S. Army Corps of Engineers, New Orleans District, accessed April 8, 2014, at https://www.google.com/url?q=http://www.mrgo.gov/ FileDownload.aspx\%3FProdType \%3Dreference $\% 26 \mathrm{id} \% 3 \mathrm{D}$ $304 \&$ sa $=$ U\&ei $=$ tpxFU5DjIcnayAHayoHYAw\&ved $=0 \mathrm{CBsQ}$ FjAA\&usg=AFQjCNHqEDDKIrdtlrSc3XNCwuCqJ0kxjw.

U.S. Army Corps of Engineers, 2010, MRGO-Mississippi River Gulf Outlet-Ecosystem restoration plan feasibility study - History of MRGO: U.S. Army Corps of Engineers, New Orleans District, accessed October 1, 2010, at http:// www.mrgo.gov/MRGO_History.aspx.

U.S. Army Corps of Engineers, 2011, Fact sheet for MRGO ecosystem restoration: U.S. Army Corps of Engineers, New Orleans District, accessed May 16, 2013, at http://www. mrgo.gov/products/MRGO_ecosystem_restoration_fact_ sheet_apr_2011.pdf.

U.S. Army Corps of Engineers, 2012, Decision Record - Individual environmental report supplemental \#11.d Improved protection on the Inner Harbor Navigation Canal, Orleans and St. Bernard Parishes, Louisiana - IERS \#11.d Tier 2 Pontchartrain: U.S. Army Corps of Engineers, New Orleans District, accessed January 21, 2014, at http://www. nolaenvironmental.gov/nola_public_data/projects/usace levee/docs/original/FinalIERS11dTier2_DR30May12.pdf.
U.S. Army Corp of Engineers, 2013a, IHNC-Lake Borgne surge barrier fact sheet: U.S. Army Corps of Engineers Team New Orleans, accessed November 20, 2013, at http://www.mvn.usace.army.mil/Portals/56/docs/PAO/ FactSheets/IHNC-LakeBorgneSurgeBarrier613.pdf.

U.S. Army Corp of Engineers, 2013b, Hurricane and storm damage risk reduction system, Lake Pontchartrain and Vicinity_St. Bernard Parish: accessed November 20, 2013, at http://www2.mvn.usace.army.mil/pd/projectslist/home. asp?projectID $=216$.

U.S. Army Corps of Engineers, 2013c, Bonnet Carre Spillway operation information: accessed November 19, 2013, at http://www.mvn.usace. army.mil/Missions/MississippiRiverFloodControl/ BonnetCarreSpillwayOverview/ SpillwayOperationInformation.aspx.

Wagner, R.J., Boulger, R.W., Jr., Oblinger, C.J., and Smith, B.A., 2006, Guidelines and standard procedures for continuous water-quality meters-Station operation, record computation, and data reporting: U.S. Geological Survey Techniques and Methods 1-D3, 51 p., 8 attachments.

Wilde, F.D., ed., variously dated, Field measurements: U.S. Geological Survey Techniques of Water-Resources Investigations, book 9, chap. A6, accessed September 22, 2010, at http://pubs.water.usgs.gov/twri9A/. 


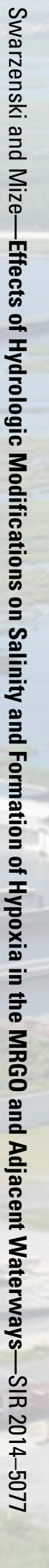

